

\title{
Introduction
}

\author{
Global green bond market size: \\ - Cumulative issuance since 2007: USD521bn \\ - USA leading with USD118.6bn, followed by China (USD77.5bn) and France (USD56.7bn) \\ - 2018 issuance: USD167.6bn ${ }^{A}$ (2017: USD162.1bn)

\begin{abstract}
2018 labelled bond market size
- USD167.6bn green bonds, which meet the CBI green bond database screening criteria ${ }^{\mathrm{B}}$

- USD21.0bn sustainability / SDG / ESG bonds and loans financing green and social projects

- USD14.2bn social bonds financing social projects
\end{abstract} \\ - USD23.7bn green bonds, which do not meet the CBI green bond database screening criteria \\ Outlook for 2019 and beyond: \\ - Green bond growth expected from financial institutions, sovereigns, Certified Climate Bonds \\ and climate-aligned issuers ${ }^{B}$ \\ - Continued harmonisation of taxonomies and use of green bond guidelines \\ - Growth of other labelled issuance (sustainability/SDG bonds and social bonds)
}

\section{About this report}

This report is the first publication in the annual series of the global Green Bonds State of the Market. It focuses primarily on labelled green bonds and uncovers the latest developments on a global scale. It looks at trends in green bond issuance and identifies avenues for market growth.

\section{About the Climate Bonds Initiative}

The Climate Bonds Initiative is an international investor-focused not-for-profit organisation working to mobilise the USD100tn bond market for climate change solutions. The mission focus is to help drive down the cost of capital for large-scale climate and infrastructure projects and to support governments seeking increased capital markets investment to meet climate goals.

\section{Contents}

4 The 2018 global green bond market

9 Spotlight on green bond post-issuance reporting

10 Developed markets in 2018

12 Emerging markets in 2018

18 The role of financial institutions

20 Spotlight on green retail products

21 The role of government

22 Policy update

23 The wider labelled bond universe

252019 outlook

Notes: A. Figure adjusted upward, compared to the 2018 Green Bond Market Summary report. B. See below.

\section{Understanding green bonds and climate-aligned}

\section{Green bonds}

Green bonds are issued in order to raise finance for climate change solutions. The key is for the proceeds to go to green assets. They can be issued by central and local governement, banks or corporations. The green bond label can be applied to any debt format, including private placement, securitisation, covered bond, and sukuk, as well as labelled green loans which comply with the Green Bond Principles (GBP) or the Green Loan Principles (GLP)., ${ }^{2,3}$

\section{Green definitions}

$\mathrm{CBI}$ uses the Climate Bonds Taxonomy, which features eight sectors: energy, buildings, transport, water, waste, nature-based assets, industry and ICT. ${ }^{4}$ See page 26 for a summary overview.

\section{Certified Climate Bonds}

$\mathrm{CBI}$ also develops sector criteria with expert input from the international science community and industry professionals. ${ }^{5}$ Issuers can certify their green issuance under the Climate Bonds Standard and Sector Criteria. ${ }^{6}$ Independent approved verifiers provide a third-party assessment that the use of proceeds complies with the objective of capping global warming at $2^{\circ} \mathrm{C}$.

\section{Inclusion in the CBI green bond database}

Only bonds with at least $95 \%$ proceeds dedicated to green assets and projects that are aligned with the Climate Bonds Taxonomy are included in our green bond database and figures. The full version of the $\mathrm{CBI}$ Green Bond Database Methodology is available online. ${ }^{7}$

\section{Climate-aligned issuers}

Climate-aligned issuers are entities which generate at least 75\% of their revenues from green business lines. CBI distinguishes between fully-aligned issuers with $95 \%$ or more green revenues, and strongly-aligned issuers (75-95\% green revenues).

The term "aligned outstanding bonds" underscores the fact that for strongly-aligned issuers $\mathrm{CBI}$ takes only a proportion of their outstanding bonds into account, and this proportion is the same as the percentage green revenues represent of their total revenues. For fully-aligned issuers, the full amount of their outstanding bonds is included in climate-aligned bond figures.

\section{Climate-aligned bond universe}

This term is used to describe the universe of aligned outstanding bonds from climate-aligned issuers and green bond issuers. ${ }^{8}$ 


\section{Top 5 in 2018: Green bond issuance rankings}

\begin{tabular}{lllll} 
No. $\mathbf{1}$ & No. 2 & No. 3 & No. 4 & No. 5 \\
USA & China & France & Germany & Netherlands \\
Amount: & Amount: & Amount: & Amount: & Amount: \\
USD34bn & USD31bn & USD14bn & USD7.6bn & USD7.4bn \\
Market share: & Market share: & Market share: & Market share: & Market share: \\
$\mathbf{2 0 \%}$ & $\mathbf{1 8 \%}$ & $\mathbf{8 \%}$ & $\mathbf{5 \%}$ & $\mathbf{4 \%}$ \\
Issuers: $\mathbf{6 3}$ & Issuers: $\mathbf{6 9}$ & Issuers: $\mathbf{1 2}$ & Issuers: $\mathbf{1 4}$ & Issuers: $\mathbf{6}$ \\
\hline
\end{tabular}

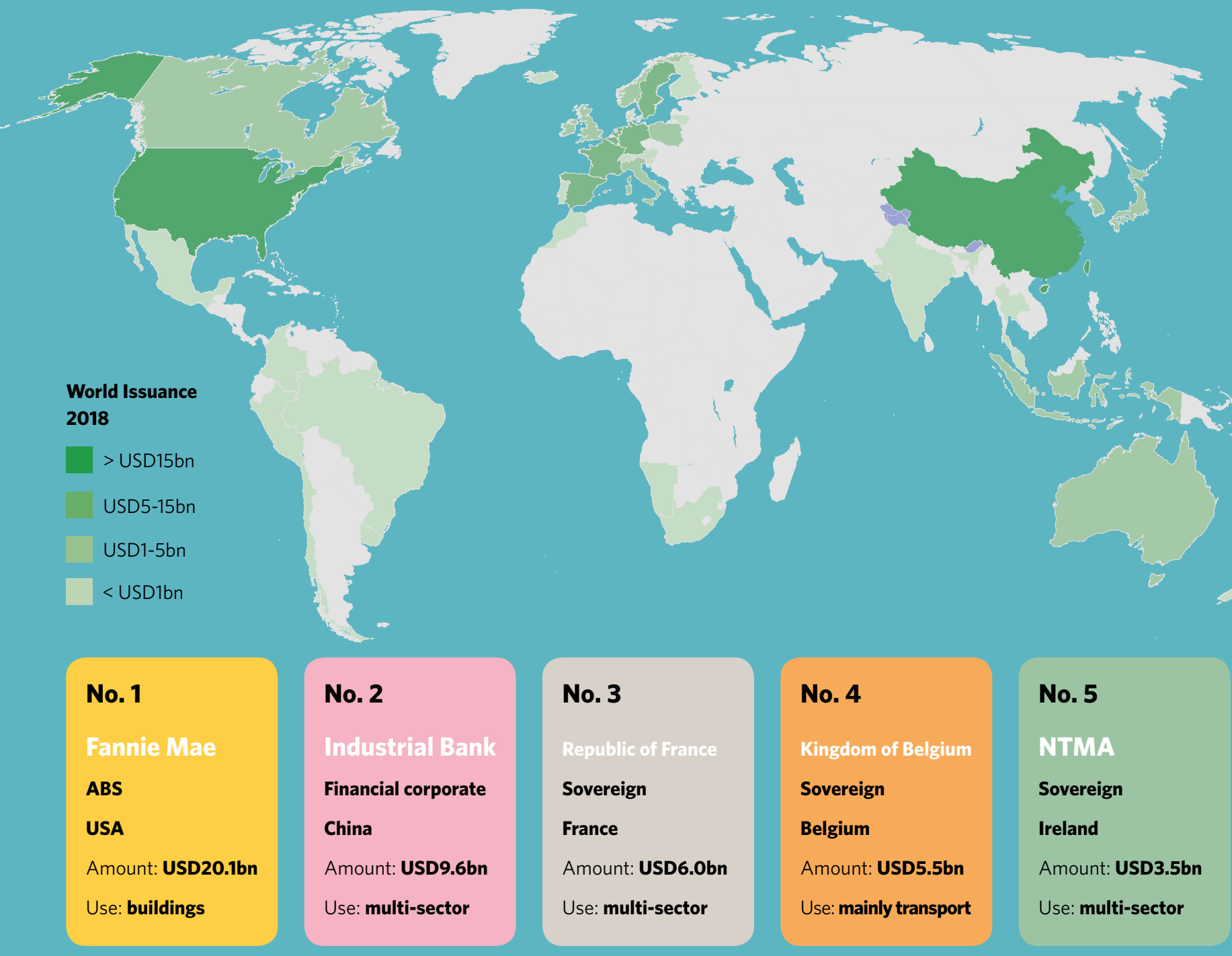

The largest green bond markets tend to have high levels of reporting

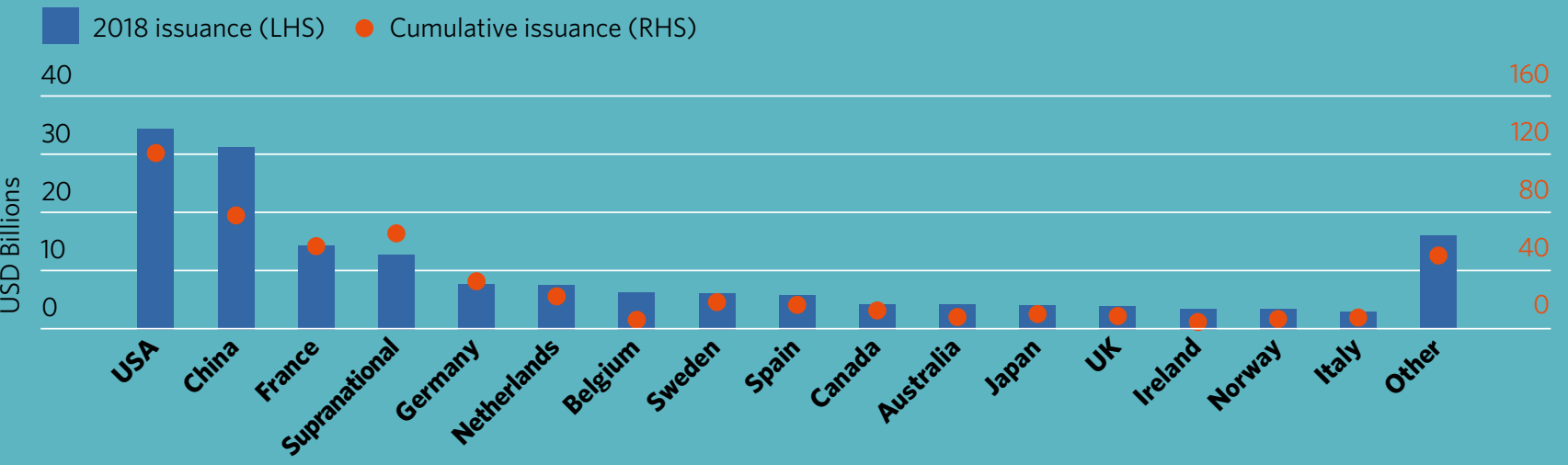




\section{The $\mathbf{2 0 1 8}$ green bond market in numbers}

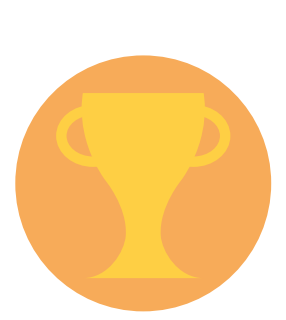

Top 3 countries

1. USA (USD34.2bn)

2. China (USD31bn)

3. France (USD14.2bn)

\section{Top 3 issuers}

1. Fannie Mae, USA (USD20.1bn)

2. Industrial Bank, China (USD9.6bn)

3. Republic of France (USD6bn)
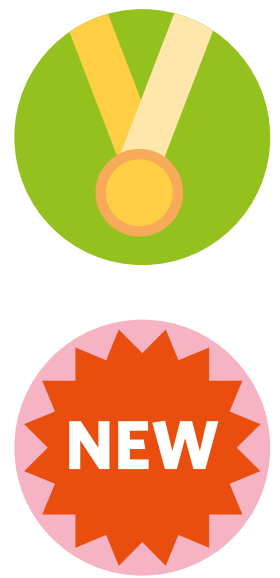

Top 3 most frequent issuers

1. Fannie Mae (1,098 deals)

2. EIB (14)

3. Vasakronan (13), World Bank (13)

\section{New issuers}

- $12 \%$ of deal count issued by new entrants, 40\% excluding Fannie Mae (2017: 7\%, 24\%)

- $31 \%$ of volume attributed to debut issuers, 35\% excluding Fannie Mae (2017: 18\%, 22\%)

\section{Deal size}

- $6 \%$ benchmark-sized deals (USD500m+), 21\% excluding Fannie Mae (2017: 6\%, 23\%)

- Median deal size USD20m (2017: USD22m), USD128m excluding Fannie Mae (USD138m)

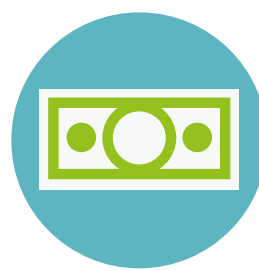

\section{Deal currency}

- $88 \%$ of deals in hard currency, $60 \%$ without Fannie Mae (2017: 90\%, 63\%)

- Deals issued in 30 currencies (2017: 25)

- Top 3 currencies: EUR, USD, CNY

\section{External reviews}

- $95 \%$ of deals received an external review, $83 \%$ excluding Fannie Mae (2017: 96\%, 87\%)

\section{Top 3 green bond market trends in 2018}

1. The rise of a broader range of socially-conscious debt labels (SDG bonds, social bonds, blue bonds) was clearly visible, providing other avenues for responsible investment.

2. The return of volatility to financial markets negatively impacted overall bond sales.

3. Revised taxonomies and further work on harmonization

- March 2018: Loan Market Association (LMA) published the Green Loan Principles (GLP), with the support of the International Capital Market Association (ICMA) ${ }^{2}$

- September 2018: Climate Bonds Taxonomy updated with new sectors and clearer definitions s,5,7 $^{4}$

- H2 2018: EU Technical Expert Group (TEG) on sustainable finance began the development of a EU green finance taxonomy. It published a consultation paper in December. ${ }^{74}$

\section{8 new markets, 204 new issuers}

Issuance from the 8 new green bond markets in 2018 - Iceland, Indonesia, Lebanon, Namibia, Portugal, Seychelles, Thailand and Uruguay - amounted to USD3.3bn.

The 204 debut green bond issuers accounted for USD61.2bn of issuance, or $37 \%$ of the annual market volume (2017: 161 issuers, $35 \%$ share). $30 \%$ of debut issuer volume was attributed to financial corporates, mainly commercial and property banks.

\section{0 repeat issuers: $63 \%$ of 2018 volume}

USD106bn was issued by 130 repeat issuers. Most came back to market once. However, a third of repeat issuer volume came from 9 entities that issued 5 or more deals in the course of the year.

\begin{tabular}{|r|r|r|}
\hline $\begin{array}{l}\text { Number of } \\
\text { repeat issuers }\end{array}$ & $\begin{array}{l}\text { Frequency (number } \\
\text { of deals in 2018) }\end{array}$ & $\begin{array}{l}\text { Share of repeat } \\
\text { issuer volume }\end{array}$ \\
\hline $\mathbf{9 0}$ & 1 & $30 \%$ \\
\hline $\mathbf{2 1}$ & 2 & $18 \%$ \\
\hline $\mathbf{5}$ & 3 & $5 \%$ \\
$\mathbf{5}$ & 4 & $15 \%$ \\
$\mathbf{9}$ & 5 or more & $32 \%$ \\
\hline
\end{tabular}

A quarter of repeat issuers' volume came from non-financial corporates, mainly utilities, real estate and transport. Repeat sovereign issuance stood at $17 \%$ of the 2018 repeat issuer total, as a result of two taps of the French Green OAT (EUR6bn) and a second green bond from Poland (EUR1bn). In February 2019 France raised a further EUR1.7bn, and at the time of writing Poland was in the market with a EUR2bn deal, which points to a trend of annual green issuance to finance the transition to a low-carbon economy.

\section{Highest growth rate: Asia-Pacific region}

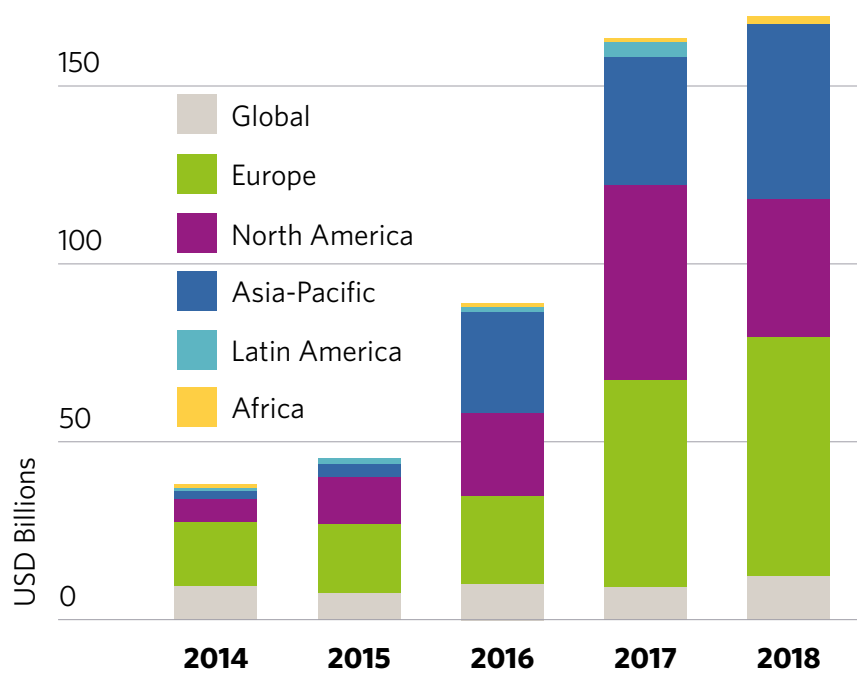

Asia-Pacific achieved the highest regional year-on-year growth rate at $35 \%$ and had the second largest 2018 volume after Europe. The bulk of the regional growth can be attributed to the increasing weight of financial corporate issuers in the market, representing more than half of Asia-Pacific issuance volumes in 2018. Issuance from non-financial corporates, green loans, government-backed entities, sovereigns and local government also rose steadily.

In 2018, the top 3 Asian-Pacific countries were China (USD31bn), Australia (USD4.2bn) and Japan (USD4.1bn). China performed strongly with the top two regional issuers being Industrial Bank (USD9.6bn) and ICBC (USD2.3bn).

Supranationals ('Global' in the chart) ranked second in terms of growth for $2017 / 18$ at $34 \%$. The top three green bond issuers for the year were the EIB (USD5.6bn), World Bank (USD2.4bn) and Asian Development Bank (USD1.7bn). North American Development Bank was a debut green bond issuer in 2018. 
Notably, however, multilateral development banks have stepped up their support for emerging market (EM) deals by investing in debut green bond issuance. The IFC was active both as a prominent private placement investor and as a key investor in the Amundi Emerging Green One Fund, set up in 2018 to invest specifically in green bonds from EM financial institutions. ${ }^{36}$

European issuers observed the third-largest year-on-year regional growth rate at $15 \%$. This secures Europe's top spot as largest green bond market overall, with USD190bn of issuance since 2007.

\section{Financial institutions fuelled 2018 market growth}

2018 set a precedent for financial institutions and their role in the green bond market. It has seen their green bond issuance more than double compared to 2017, a remarkable achievement.

Commercial banks were the most active of all financial institutions. Their issuance nearly doubled from 2017 levels with contributions from a wide variety of institutions, from the second largest global issuer Industrial Bank (China) to one of the most recent market entrants, Bank Windhoek (Namibia).

Property banks and real estate investment trusts (REITs) were also very much involved, the vast majority from developed markets. Four property banks entered the green bond market in 2018, spurring green covered bond growth, while the geographic diversity of REIT issuance greatly increased, together with volumes.

The section on page 18 further expands on the role of financial institutions in greening the economy.

\section{Sovereigns were prolific issuers in 2018}

The USD17.5bn worth of sovereign green bond issuance in 2018 accounts for $10 \%$ of the global volume. Indonesia, Belgium, Lithuania, Ireland and Seychelles were the new sovereign issuers.

Green bonds from sovereigns increase awareness of the country's climate plan, and can help fund commitments under the Paris Agreement. It has been reported that Spain, the Netherlands, Hong Kong and Egypt could join the sovereign ranks this year. ${ }^{9,10,11,12}$

Sovereign and other public sector issuance is covered in more detail in the section on page 21 , which highlights their role in greening public infrastructure and public services.

\section{EUR surpassed USD as the denomination of choice}

The preferred currency in 2018 was the Euro, representing $40 \%$ of the annual market by volume. In 2017, the US dollar was leading at $46 \%$ of annual volume.

This change is partly due to the drop in US municipal issuance (-70\% in terms of volume, see page 21) as well as large-scale issuance from Eurozone sovereigns (France, Belgium, Ireland) and other European issuers (e.g. Poland, Norwegian covered bond issuers).

The 5 most common currencies in 2017 accounted for $94 \%$ of the annual volume. In 2018, the share of the top 5 decreased to $91 \%$.

Chinese Renminbi remains the third most popular denomination currency, as a result of continued robust green bond market growth of China's domestic market.

In 2018, five new currencies featured in the green bond market: CLF, ISK, KRW, NAD and THB. This is a sign of continuing diversification and appeal to a wider range of domestic issuers. For instance, South Korean issuers had previously issued only in hard currency, but in 2018 the first local currency green bond deal emerged. Greater local volumes of local currency issuance can help improve the visibility of domestic markets to foreign green bond investors.
Cumulative regional green bond issuance since 2007

\begin{tabular}{|c|c|c|c|c|}
\hline Region & $\begin{array}{l}\text { Green bond } \\
\text { markets }\end{array}$ & Issuers & $\begin{array}{l}\text { Amount } \\
\text { issued } \\
\text { (USDbn) }\end{array}$ & $\begin{array}{l}\text { Change } \\
2017-18\end{array}$ \\
\hline Africa & 4 & 11 & 2 & $v$ \\
\hline Asia-Pacific & 18 & 222 & 120 & N \\
\hline Europe & 22 & 193 & 190 & N \\
\hline Supranationals & - & 11 & 66 & N \\
\hline Latin America & 7 & 24 & 7 & $V$ \\
\hline North America & 3 & 167 & 137 & v \\
\hline
\end{tabular}

Note: Cumulative data as of 31 December 2018

Financial institutions fuelled 2018 market growth

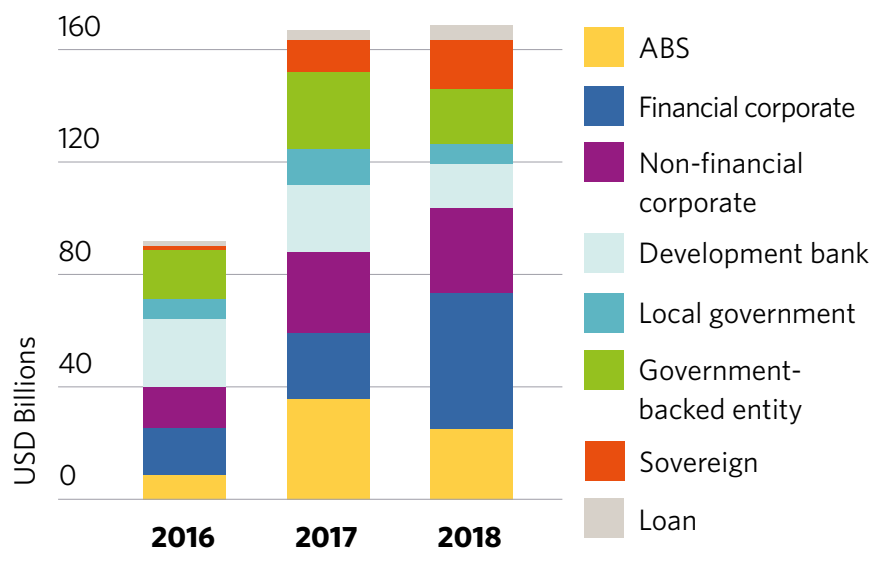

Sovereign green bond issuers to date

\begin{tabular}{|l|r|r|r|}
\hline Nation & Debut & Total issued and issue currency \\
\hline Belgium & Mar 2018 & USD5.5bn & EUR4.5bn \\
\hline Fiji & Nov 2017 & USD49m & FJD100m \\
\hline France & Jan 2017 & USD16.7bn & EUR14.8bn \\
\hline Indonesia & Mar 2018 & USD2bn & USD2bn \\
\hline Ireland & Oct 2018 & USD3.5bn & EUR3bn \\
\hline Lithuania & May 2018 & USD24m & EUR2Om \\
\hline Nigeria & Dec 2017 & USD30m & NGN10.7bn \\
\hline Poland & Dec 2016 & USD2bn & EUR1.8bn \\
\hline Seychelles & Oct 2018 & USD15m & USD15m \\
\hline
\end{tabular}

Euro was the most popular currency by volume in 2018

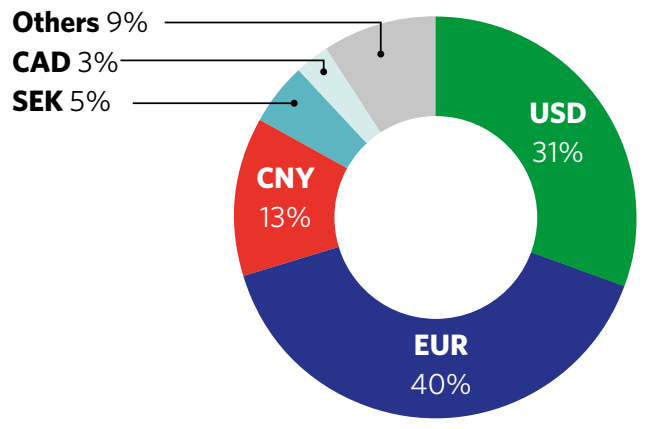




\section{Average green bond size was highest in 2018}

Over time, green bonds have exhibited a growth in average deal size. This is positive as larger deals can provide more liquidity and depth to the market, and thus attract additional investors.

The average green bond deal size in 2018 was USD107m, slightly up from 2017, when it was USD104m. However, the trend is more pronounced, when Fannie Mae deals are excluded, as nearly all the agency's issues are up to USD100m. Excluding Fannie Mae, the average size of deals issued in 2018 was USD320m, or the same as 2017, but higher than the USD294m achieved in 2016 and 74\% up on the 2015 average of USD184m.

A similar trend is observed with median deal size. At USD129m in 2018, it is a bit lower than in 2017 (USD138m) but higher than in 2016 (USD117m) and 2.6x the 2015 amount (USD50m). The growth in the median size indicates that more issuers are issuing larger deals, whereas the growth in average size is driven more significantly by the volume of large-bond deals.

In 2018, 24 issuers closed green bonds of USD1bn or more. The largest single deal of 2018 came from the Kingdom of Belgium: EUR4.5bn (USD5.5bn). In terms of issuer type, the largest green bond issuers tend to be financial corporates (China predominantly), and sovereigns (Belgium, France, Indonesia, Ireland and Poland).

Supranationals ('Global' in the graph) had the highest median deal size (USD169m), followed by Asia-Pacific issuers (USD146m). The median deals size is below USD100m in Latin America, North America and Africa. In emerging markets this is perhaps not surprising. In North America, Fannie Mae's green MBS made up 93\% of the region's 2018 deal count and their median size was USD14m. Even excluding Fannie Mae deals, the median bond size was USD100m, as US Muni issuance is also often at the low end.

All in all, a significant number of smaller deals have come to market across regions. This demonstrates that entities with lower funding requirements and/or those issuing green bonds for the first time can also get access to capital markets funding.

More information on support mechanisms and risk sharing, which can help smaller issuers come to market, is provided in our ASEAN Green Financial Instruments Guide..$^{13}$ Despite being somewhat tailored to ASEAN stakeholders, most of these instruments can be used in other parts of the world too.

\section{8 green bonds were shorter-dated}

In 2018, bonds within the 'Up to $5 Y^{\prime}$ ' range made up the largest tenor category, while the ' $5-10 Y^{\prime}$ ' bracket was the largest in 2017, with a quarter of the annual issuance volume. 2018 deals with a 5-10Y tenor amounted to a similar volume as last year, but represented $37 \%$ of annual issuance as long-dated deals of $20 \mathrm{Y}$ or more decreased in volume.

This preference towards short-dated bonds is partly associated with the increased issuance from commercial banks, which tend to issue bonds with a short tenor. In addition, they were popular with government-backed entities and nonfinancial corporates: a shift away from the 2015-2017 trends, when these issuer types favoured the ' $5-10 Y$ ' tenor range. Finally, green bond issuance from US municipalities dropped in 2018 compared to 2017, and as these deals tend to be longer-dated, their decreased share reinforced the trend.

One could also possibly attribute part of the shift to higher market volatility and rising interest rates in 2018 . Short-duration strategy is a way of reducing exposure to interest rate risk.
Green bond deals have grown across size brackets

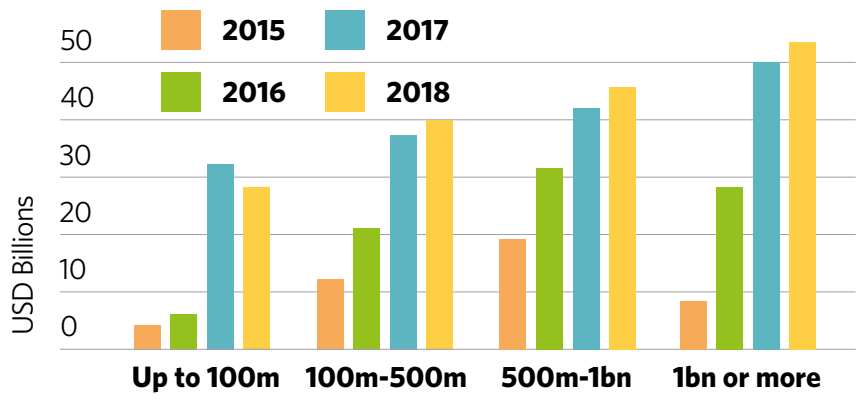

More small deals than large: median deal size was below USD170m across regions in 2018

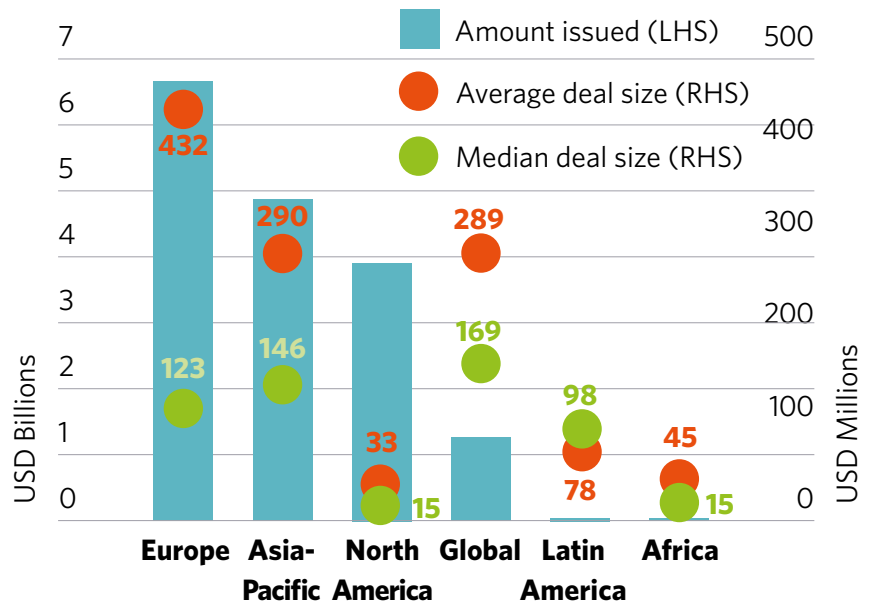

Top 10 issuers in 2018

\begin{tabular}{|l|l|}
\hline Developed markets & Emerging markets \\
\hline 1. Fannie Mae (US) & Industrial Bank Co., Ltd (CN) \\
\hline 2. Republic of France (FR) & ICBC (CN) \\
\hline 3. Kingdom of Belgium (BE) & Bank of China (CN) \\
\hline $\begin{array}{l}\text { 4. National Treasury } \\
\text { Management Agency (IE) }\end{array}$ & Republic of Indonesia (ID) \\
\hline 5. ING (NL) & Republic of Poland (PL) \\
\hline 6. Iberdrola (ES) & China Three Gorges Corp (CN) \\
\hline 7. Bank of America (US) & Beijing Infrastructure Investment (CN) \\
\hline 8. Société du Grand Paris (FR) & Bank of Guiyang (CN) \\
\hline 9. KfW (DE) & Bank of Guizhou (CN) \\
\hline 10. DNB Boligkreditt AS (NO) & State Bank of India (IN) \\
\hline
\end{tabular}

2018 green bonds were shorter-dated than 2017's

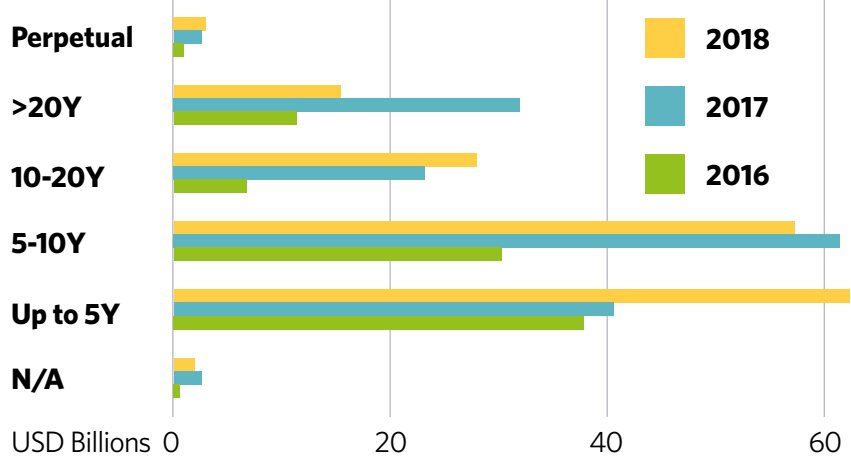




\section{Securitisation remained popular due to Green MBS}

Senior unsecured bonds are the most common green bond format, but the market has seen an increasing diversification of other bond types. Securitisation remained the second largest bond format, driven by the USD2Obn issued by Fannie Mae.

However, in 2018, there was a notable surge in popularity for covered bonds, MTNs, sukuk and green loans.

\section{Covered bonds / Pfandbriefe}

Covered bond issuance rose from USD1.1bn in 2017 to USD6bn last year. Anchored in the German green bond market since 2015, green covered bonds got a boost in 2018 as two large Norwegian mortgage banks and a Swedish land mortgage bank entered the market. This diversified cover pools into low-carbon housing and sustainable forestry. Building on 2018 trends, Swedish mortgage bank SCBC issued its debut green covered bond in January 2019.

Covered bonds are highly-regulated securities with superior credit ratings. They achieve lower funding cost than unsecured debt thanks to a dual recourse structure whereby bond investors have a general claim against the issuer, as well as a claim over a dedicated 'cover' pool of assets. Cover pool composition is closely monitored.

\section{MTN}

Issuance under Medium-Term Note (MTN) facilities went from USD1.4bn in 2017 to USD4.6bn in 2018. Fabege (Sweden) created the first green MTN program in 2016. Originally mostly popular amongst Swedish issuers, green bonds issued under a green or mixed MTN expanded their reach to other markets. In 2018, the green bond market saw the issuance of the first ASEAN Green MTN Facility by Malaysian JV Segi Astana.

MTN structures are a valuable tool as they can be deployed by repeat issuers to facilitate access to the market and lower deal costs. They can be structured to allow for a variety of currency denominations and debt formats to increase their flexibility.

\section{Sukuk}

Securities Commission Malaysia revised its Islamic Securities Guidelines in 2014 to provide standards for socially responsible investment (SRI). This laid the ground for the first green sukuk, which came from Malaysia in 2017. Sukuk issuance doubled from USD755m in 2017 to USD1.4bn last year.

Six entities have used sukuk to finance climate projects. The Republic of Indonesia has now closed two multi-sector deals (USD2bn): one in 2018 and a second in 2019. In Malaysia, Permodalan Nasional Berhad issued a green sukuk (MYR1.9bn / USD461m) to finance low-carbon buildings, while Quantum Solar Park, Mudajaya Group, Tadau Energy and UITM Solar Power raised funding for solar.

\section{Green secured debt}

Overall, about a quarter (23\%) of 2018 green bond issuance relates to deals with ringfenced collateral or access to a cover pool. In addition, to the benefit of security, these deals provide investors with certainty around allocations, as the collateral pool is defined pre-issuance and is known at closing. This may also be the case for unsecured bonds occasionally, but the vast majority of unsecured bonds only indicate the eligible categories at issuance.

In 2018, National Australia Bank created a secured debt product which gives investors a participation share in and security over a loan portfolio. The approach is similar to loan syndication, but it involves a portfolio, making the structure suitable for aggregation.

\section{Top 5 bond types in the 2018 green bond market}

\begin{tabular}{|l|r|r|}
\hline Bond type & Amount issued & $\% 2018$ \\
\hline Senior unsecured & $98 \mathrm{bn}$ & $59 \%$ \\
\hline ABS/MBS & $24.6 \mathrm{bn}$ & $15 \%$ \\
\hline Senior secured & $6.8 \mathrm{bn}$ & $4 \%$ \\
\hline Covered bond & $6 \mathrm{bn}$ & $3.5 \%$ \\
\hline Loan & $5.1 \mathrm{bn}$ & $3 \%$ \\
\hline
\end{tabular}

\section{New senior bond formats emerging to address} new bank capital management rules

New bond formats emerged for green bonds in Europe over the last few years. For example, Crédit Agricole CIB issued a EUR1bn green bond in senior preferred unsecured debt format. ${ }^{14}$

BNP Paribas, BBVA and Commerzbank issued green bonds in non-preferred senior (NPS) unsecured debt format. NPS vanilla bonds have been widely used by French banks since 2016, by Spanish and Belgian banks in 2017, and were introduced in Italy and Germany in 2018. ${ }^{15}$

A new EU Directive adopted in December 2017 has enabled EU banks, large investments firms and group companies to issue 'senior non-preferred' debt instruments. The law modifies the hierarchy of claims in case of resolution and allows the creation of the new class of NPS instruments between subordinated debt and senior unsecured debt (i.e. the preferred senior debt). There has been a positive response of the market as it complies with the new requirement for loss-absorbing liabilities, ${ }^{16}$ and BBVA issued the first green NPS bond in May 2018. ${ }^{17}$

\section{Labelled green loans}

Green loans finance green assets. The Loan Market Association (LMA) published the Green Loan Principles in March 2018 specifically to support and encourage green lending.

Green loans increased from USD3.1bn in 2017 to USD5.1bn in 2018, with high uptake in Spain, Singapore and USA. Real estate entities issued $32 \%$ of green loans by amount, followed by the energy sector (24\%). Loans were also used to finance certified paper manufacturers and waste management projects.

In 2019, the IFC announced it will adopt the GLP to help spur the growth of the USD33bn green loan market. ${ }^{88}$

\section{Repacks such as Fannie Mae REMICs}

Sometimes green debt instruments are bundled together to create new securities, thus expanding investment product options for investors, or are refinanced back-to-back with green bonds, e.g. in the context of a development bank supporting local currency issuance in an emerging market. To avoid doublecounting, CBI maintains a separate tally of repack deals.

The largest issuer so far is Fannie Mae. It issues multi-tranche securitisations, called REMICs, with tranches secured on Green MBS. To date, it has issued USD7.1bn in nine REMICs - five Green REMICs, the rest as green tranches in wider deals..$^{18}$ 


\section{Almost $90 \%$ of deals have external reviews}

89\% of green bonds issued in 2018 (by amount) received at least one external review. Second party opinions remain the preferred option. Certification under the Climate Bonds Standard is the second largest category. Green bond ratings are gaining ground and are now provided by global rating agencies Moody's and S\&P, nine agencies in China, R\&I and JCR in Japan, and RAM in Malaysia.

CICERO was the leading provider of external reviews in 2018, representing $28 \%$ of deals by volume and $81 \%$ by count. CICERO's high market share in terms of deal numbers can be explained by the fact that Fannie Mae issued more than 1,000 green MBS in 2018 with a CICERO SPO. In turn, these green MBS accounted for $75 \%$ of deals with an external review in 2018.

Sustainalytics was the second largest. It helped 43 new issuers with USD27bn of deal volume enter the market.

In 2018, European issuers accounted for $56 \%$ of Certified Climate Bonds by volume, followed by Asia-Pacific issuers at $39 \%$. This is a regional shift from 2017, where Asia-Pacific was the largest category (50\%), in front of North America (28\%).

$14 \%$ of green bonds issued in 2018 by volume were awarded Certification under the Climate Bonds Standard ( 46 deals totalling USD23.3bn). Sustainalytics was the top Approved Verifier under the Climate Bonds Standard, both in terms of deal count and volume.

The top 3 Certified issuers in 2018 were:

- ING: USD3bn. About half the proceeds will finance or refinance loans to 88 onshore and offshore wind farms, whilst $15 \%$ will fund 29 solar farms. The remainder will finance buildings with an Energy Performance Certificate Label A and emissions performance within the top $15 \%$ of the Dutch market. ${ }^{19}$

- Société du Grand Paris: USD2bn. Proceeds from this bond will be used to finance the construction of almost $200 \mathrm{~km}$ of new metro lines and extensions to supplement the $400 \mathrm{~km}$ of existing lines in the lle-de-France region. The deal was the first Certified Climate Bond of a EUR3Obn programme. ${ }^{20}$

- DNB Boligkreditt: USD1.7bn. Proceeds will finance or refinance new and existing mortgages on housing which comply with the Norwegian building codes 2010 (TEK10) or 2017 (TEK17). This corresponds to the top $7 \%$ of Norwegian housing in terms of energy performance. ${ }^{21}$

\section{There was a slight increase in green bonds without an external} review in 2018, both by amount and deal count. Whilst in 2017, bonds from repeat issuers were more likely not to have an external review, in 2018, this was more prevalent among debut issuers, especially from the US and China.

Whilst it is common for US municipalities not to have an external review, 2018 differed in-so-far-as debut Chinese green bonds issuers, across the board, were less likely to have one. For instance, Chinese entities issuing green bonds on the onshore interbank market are less likely to get an external review. This represents a challenge for the market in terms of pre- and post-issuance transparency, especially if the information is only available in the local language and there is limited information in English.

An increasing number of issuers without an external review are providing similar information to what would go into a green bond framework, in the offer prospectus. As prospectus disclosure is reviewed by legal counsel, technical advisors and auditors, this provides a degree of comfort on green claims. Notwithstanding this, a separate external review would strengthen disclosure.
$89 \%$ of 2018 global issuance had an external review

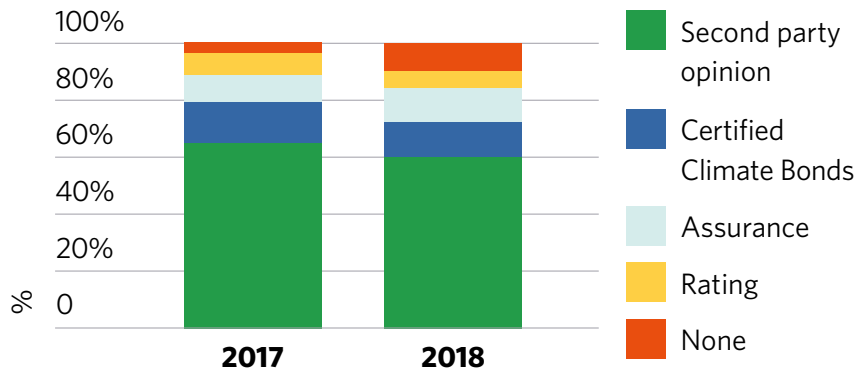

CICERO led in external reviews in 2018

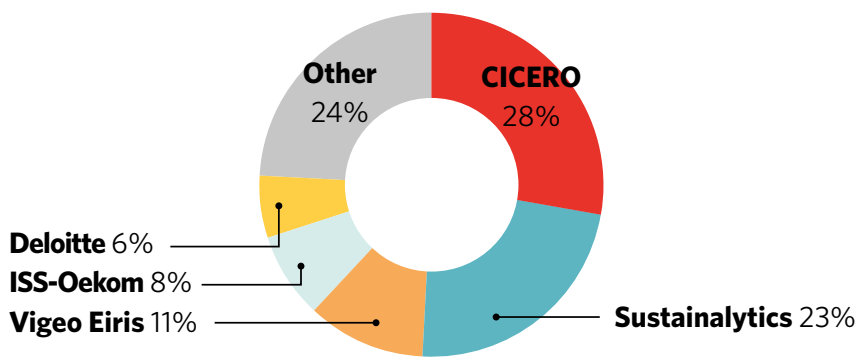

\section{$56 \%$ of the 2018 Certified Climate Bonds volume} came from European issuers

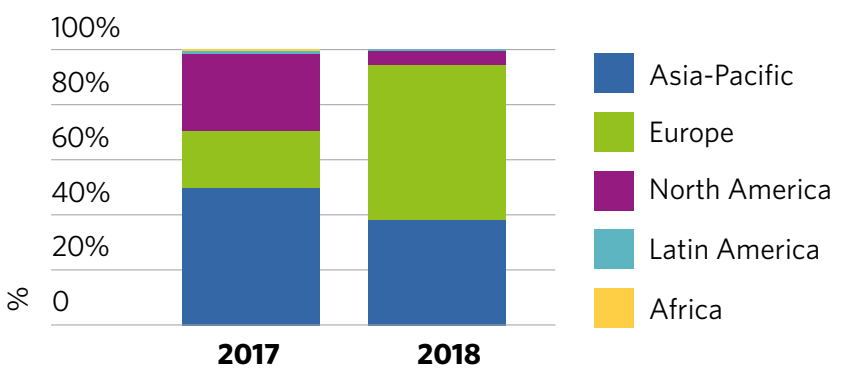

\section{External reviews}

External reviews from an independent party confirm alignment with the GBP/GLP and/or compliance with the Climate Bonds Standard. The most common forms of external review are:

Assurance: confirmation of compliance with the GBP.

Second party opinion: assessment of the issuer's green bond framework, confirming GBP compliance.

Green bond rating/evaluation: evaluation against a third-party rating methodology, which considers the environmental aspects of the investment (separately from credit ratings).

Verification for Certified Climate Bonds: third-party verification, pre- and post-issuance, which confirms that assets adhere to the Climate Bonds Standard and Sector Criteria.

For more, see Appendix 1, page 26.

\section{Certified Climate Bonds}

Issuers can certify green issuance under the Climate Bonds Standard. ${ }^{6}$ Certification confirms that the bond is aligned to the Paris Agreement, i.e. to keeping global warming under $2^{\circ} \mathrm{C}$.

A third-party Approved Verifier assesses the assets to confirm compliance with Climate Bonds Standard and sector-specific Criteria. Post-issuance, the issuer must obtain an annual post issuance verification to maintain its Certified status. 


\section{Post-issuance reporting in the green bond market}

In 2018, CBI undertook research into post-issuance reporting practices for the second time. The findings are summarised and analysed in our study Post-issuance reporting in the green bond market, published in March 2019, and compared to the previous findings set out in our inaugural report from June 2017.22,23

The analysis covers post-issuance reporting data for 1,927 bonds issued prior to November 2017 by 369 issuers. The purpose of this research is twofold. It pivots on assessing whether issuers are reporting, but it also provides an update on the allocation of proceeds that are recorded on $\mathrm{CBI}$ green bond database.

The percentage of reporting varies between use-of-proceeds (UoP) and impact metrics, and depends on whether the independent variable used is the number of bonds, the number of issuers or the issued amount (in USD) of outstanding bonds.

The proportion of reporting is $77 \%$ by bond count and $87 \%$ by amount, i.e. in line with previous findings (74\%, 88\%), if the prolific issuance from Fannie Mae is excluded. Fannie Mae deals are secured on green collateral from issuance, so they do not provide UoP reporting, but do report on impacts. This influences the overall (unadjusted) figures, as summarised in the table below.

The study considers year of issue, issuer type, country, bond size and the use of external review as variables in order to draw inferences from the use-of-proceeds and impact reporting data. $\mathrm{CBI}$ also developed a reporting quality scoring system for postissuance UoP reporting, based on aspects of information clarity, granularity and reliability.

\section{Key findings}

1. Two-thirds of issuers provide post-issuance UoP reporting. More issuers report on allocations than on environmental impact. Almost $50 \%$ of issuers report on both UoP and impact.

2. $93 \%$ of bonds, where issuers committed to reporting at issuance, did in fact report. $33 \%$ of bonds, where there was no commitment, also reported.

3. Larger issuers tend to report: the reporting percentage based on amount issued is considerably higher than by number of issuers. Benchmark-sized bonds (USD500m or more) are more likely to have reporting.

4. The reporting percentage is higher for deals with an external review post-issuance. When the external review is at issuance, e.g. SPO, the correlation is also positive but weaker.

5. Despite having the largest set of issuers reporting UoP (52), the USA is not the country with most reporting by amount issued: China ranks higher. This is linked to the large number of bank issuers, which are required to report on green bonds quarterly.

6. Countries with large green bond markets tend to have high levels of reporting, and most large markets have reporting levels of $90 \%$ or more.

7. While many issuers report impacts - with greenhouse gas emission reductions reported most often - there is little consistency, with over 200 metrics and many different frameworks used by issuers.

The percentage of green bond reporting varies significantly

\begin{tabular}{|c|c|c|c|c|c|c|c|c|c|}
\hline \multirow[b]{2}{*}{ Reporting } & \multicolumn{3}{|c|}{ Number of bonds } & \multicolumn{3}{|c|}{ Number of issuers } & \multicolumn{3}{|c|}{ Amount issued (USDbn) } \\
\hline & Reporting & $\begin{array}{l}\text { Non- } \\
\text { reporting }\end{array}$ & $\begin{array}{l}\% \\
\text { Reporting }\end{array}$ & Reporting & $\begin{array}{l}\text { Non- } \\
\text { reporting }\end{array}$ & $\begin{array}{l}\% \\
\text { Reporting }\end{array}$ & Reporting & $\begin{array}{l}\text { Non- } \\
\text { reporting }\end{array}$ & $\begin{array}{l}\% \\
\text { Reporting }\end{array}$ \\
\hline Use of proceeds & 715 & 1,190 & $38 \%$ & 251 & 116 & $68 \%$ & 223 & 58 & $79 \%$ \\
\hline Impact & 1,514 & 391 & $79 \%$ & 194 & 173 & $53 \%$ & 219 & 62 & $78 \%$ \\
\hline Both & 501 & 1,404 & $26 \%$ & 172 & 295 & $47 \%$ & 186 & 95 & $66 \%$ \\
\hline
\end{tabular}

\section{The largest green bond markets tend to have high levels of reporting}

Amount with reporting (USDbn)

100

60

(3)
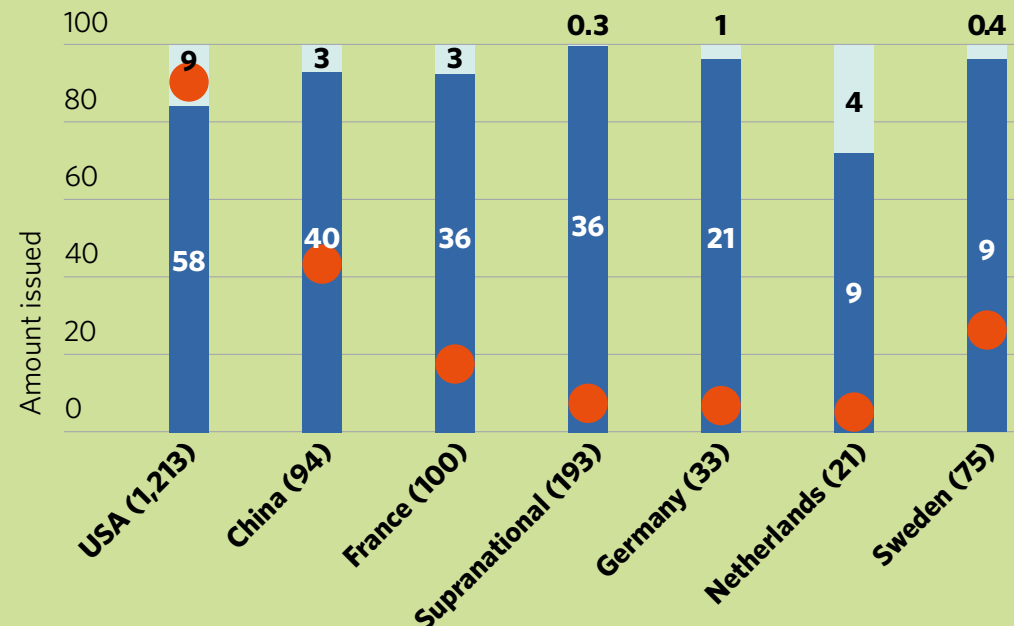

Amount without reporting (USDbn)

Number of issuers
0.1

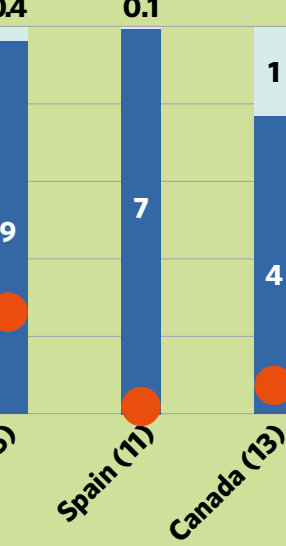

0.3
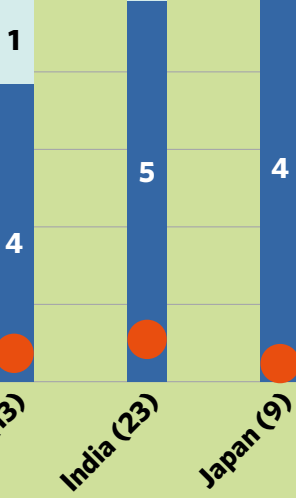

(Number of bonds)
60 


\section{Developed markets in 2018: strong performance from sovereigns and financial institutions}

\section{A quick take on the 2018 market}

- USD115bn issued, or 69\% of the overall 2018 green bond market (2017: USD115.5bn)

- Top 3 issuers: Republic of France (USD6bn), Kingdom of Belgium (USD5.5bn) and National Treasury Management Agency (USD3.5bn)

- Top 3 countries: USA (USD34.1bn), France (USD14.1bn) and Germany (USD7.6bn)

- Top 3 currencies: EUR (USD57bn, or 50\% of DM green bond volume), USD (USD38.4bn, 33\%) and SEK (USD6.4bn, 6\%)

\section{- $93 \%$ of volume in hard currency}

- 199 deals excluding Fannie Mae, of which 23\% were benchmark-size

- $\mathbf{3 9 \%}$ of volume was from debut bonds (32\% in 2017)

This section focuses on developed markets, whereby we use MSCl's market classification to categorize markets. ${ }^{24}$

\section{Financials accounted for a quarter of $\mathbf{2 0 1 8}$ volume}

Whilst DM green bond volumes did not change much from 2017 to 2018, the composition did. In 2018, financial corporates accounted for $25 \%$ of DM issuance. ING (USD3bn), Bank of America (USD2.3bn) and DNB Boligkreditt AS (USD1.7bn) were the top 3 financial corporate issuers.

Despite lower issuance from the USA, France and Germany, these countries kept their lead. A number of DM markets saw their year-onyear issuance surge: fivefold for Norway, 4.6x for Hong Kong, double or nearly-double for Singapore, Austria, the Netherlands, the UK and Australia. Sovereign issuance from Belgium and Ireland contributed to improving their global ranking and propelled Belgium into the Top 10 .

Portugal appeared in the rankings thanks to the first green bond from electricity company EDP.

DM issuance continues to be dominated by Europe. The gap between the leader and runner up, North America, widened due to the retreat of US green bond issuance (-26\%). Asia-Pacific's growth was primarily fuelled by Australia, Japan and Singapore.

\section{EUR became the dominant DM currency in 2018}

EUR was the most often used denomination currency last year, a clear shift from USD leadership in 2017. Fannie Mae and US Munis accounted for the biggest drop in USD-denominated deals. The Euro picked up thanks to issuance from financial institutions. Other currencies were also on the rise in 2018: deals in Swedish Krona doubled in volume, whilst those in Canadian dollars nearly tripled.

DM average bond size increased compared to 2017, rising from USD320m to USD351m, excluding Fannie Mae deals. Sovereign and financial institutions accounted for the main increase in volume in the 'USD1bn or more' bond size category.

2018 witnessed a significant increase in the proportion of deals of USD1bn or more among debut issuers, while their share remained about the same for repeat issuers. It is also worth noting that the share of benchmark-sized deals coming from debut issuers is significantly higher than the 50/50 split for repeat issuers. Issuance from new sovereign and financial institution issuers contributes to that too.
Top 10 DM country ranking

\begin{tabular}{|c|c|c|c|c|c|}
\hline $\begin{array}{l}2018 \\
\text { Rank }\end{array}$ & $\begin{array}{l}\text { Country of } \\
\text { risk }\end{array}$ & $\begin{array}{l}2018 \text { isst } \\
\text { USDbn }\end{array}$ & $\begin{array}{l}\text { ce } \\
\text { Deals }\end{array}$ & $\begin{array}{l}\text { Change v } \\
2017\end{array}$ & $\begin{array}{l}\text { \% DM } \\
\text { issues }\end{array}$ \\
\hline 1 & USA & 34.1 & 1,159 & $\sqrt{ }$ & $34 \%$ \\
\hline 2 & France & 14.2 & 20 & 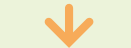 & $17 \%$ \\
\hline 3 & Germany & 7.6 & 19 & 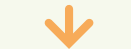 & $9 \%$ \\
\hline 4 & Netherlands & 7.4 & 8 & 1 & $6 \%$ \\
\hline 5 & Belgium & 6.3 & 3 & 1 & $2 \%$ \\
\hline 6 & Sweden & 6.1 & 58 & A & $5 \%$ \\
\hline 7 & Spain & 5.8 & 10 & $\sqrt{ }$ & $5 \%$ \\
\hline 8 & Canada & 4.3 & 9 & $\gamma$ & $3 \%$ \\
\hline 9 & Australia & 4.2 & 9 & $\phi$ & $3 \%$ \\
\hline 10 & Japan & 4.1 & 29 & 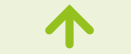 & $3 \%$ \\
\hline
\end{tabular}

Corporate bonds represent $45 \%$ of the market

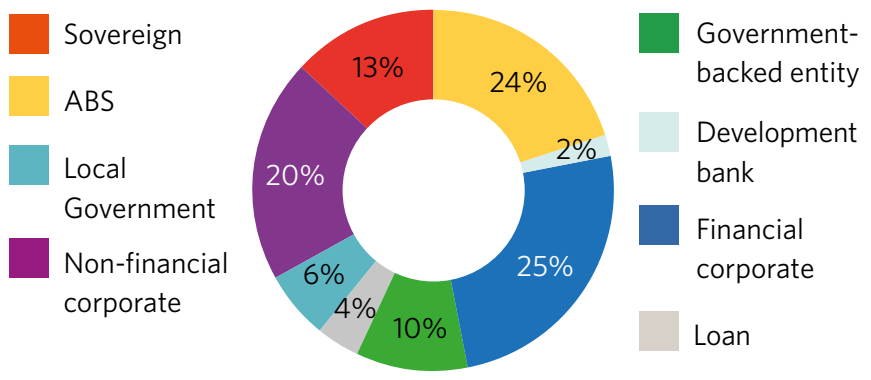

EUR became the dominant DM currency in 2018

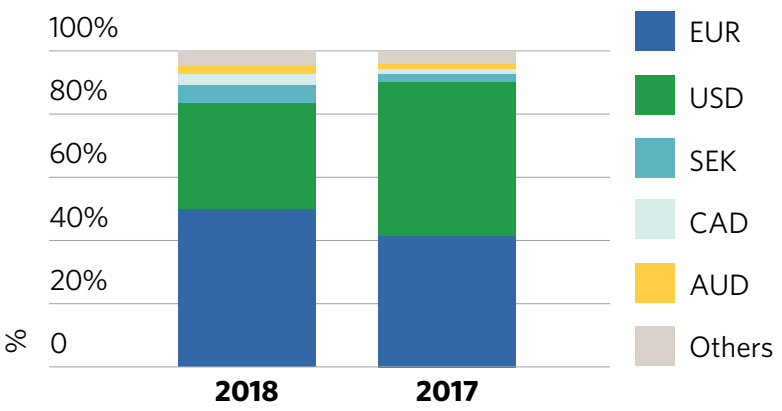

2018 debut issuers closed more 10-digit bond deals

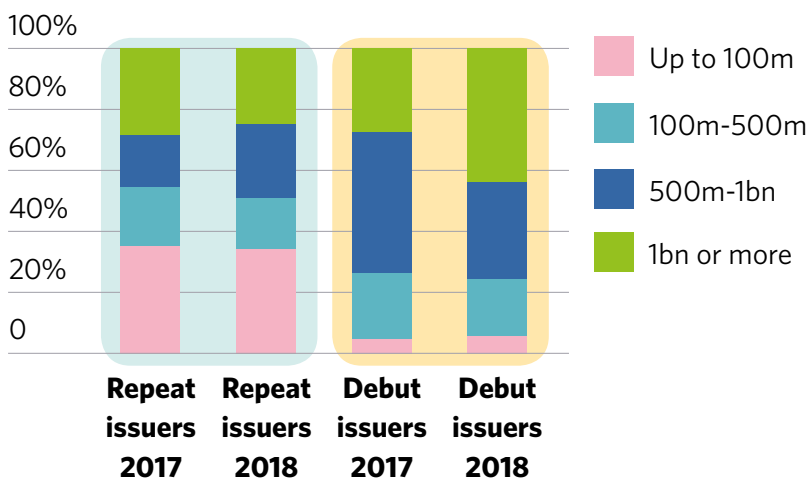


The average tenor for repeat issuers increased from 12.4 years in 2017 to 13.1 years in 2018. However, debut bonds in 2018 saw a sharp decline in their average tenor (24.7 years in 2017 versus 10.8 years the following year).

More broadly, sovereigns had the strongest preference for long-dated bonds in 2018, followed by ABS issuers (driven again by Fannie Mae). Development banks showed a strong preference for medium term bonds of 5-10 years, while most green loans had a term of up to 5 years at origination.

\section{Almost $90 \%$ of deals have an external review}

Mirroring global trends, green bonds without any external review increased from 5\% in 2017 to $11 \%$ in 2018 for DM volumes. This is primarily due to new and repeat issuance from US municipalities. Second party opinions remained the preferred external review type with CICERO leading the way.

\section{$16 \%$ of DM green bond market volume was Certified Climate}

Bonds (+13\% over 2017). The leading country was the Netherlands (USD5.1bn), followed by Norway (USD3bn). This is a noticeable shift from 2017, where the USA topped rankings (at USD6.2bn), ahead of France (USD2.5bn). It also explains the shift from the preponderance of local government being awarded Certification in 2017 (exclusively from the USA to more than half of the Certified market segment originating from financial institutions in 2018.

\section{Climate-aligned issuers could issue green bonds}

CBI's Bonds and Climate Change: The State of the Market 2018 identifies issuers, which generate at least $75 \%$ of their revenues from 'green' business: low-carbon transport, clean energy, sustainable water and wastewater management, low-carbon buildings and built environment, sustainable forestry and agriculture, as well as waste management and recycling. ${ }^{8}$ These climate-aligned issuers provide an avenue to increase labelled green issuance.

A number of climate-aligned issuers are already green bond issuers. SNCF Reseau is using Programmatic Certification for its green bonds, a streamlined process for repeat issuers to obtain Certification under the Climate Bonds Standard for multiple issues..$^{25}$ Other repeat green bond issuers are French electricity company EDF and English utility Thames Water, which has raised USD1bn for London's new super-sewer through its financing vehicle, Bazalgette Finance.

Green bonds can be used to raise funding for new business investment. Maturing bonds also present a green labelling opportunity at refinancing. Furthermore, labelling can highlight a company's ambitions in building a climate-resilient economy.
Shorter-dated bonds were popular amongst DM financial corporates in 2018

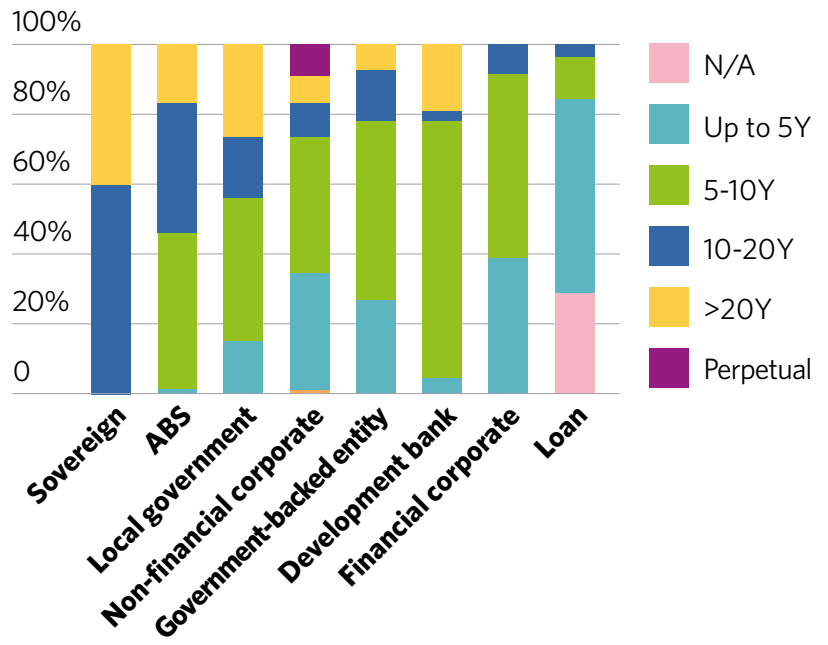

DM climate-aligned universe overview (as of mid-2018)

- 253 climate-aligned issuers

- USD489bn outstanding aligned

- Top 3 issuers: EDF, France (USD53.6bn), SNCF Reseau, France (USD39.2bn) and Network Rail, UK (USD33bn)

- Top 3 countries: France (USD132bn), USA (USD99bn), UK (USD92bn). USA, UK and Canada by number of issuers.

- Top 3 sectors: Transport (USD257bn), Energy (USD128bn), Water (USD68bn)

- Top 3 currencies: EUR (USD176bn, or 36\% of the universe), USD (USD140bn, 29\%) and GBP (USD103bn, 21\%)

Top 10 DM climate-aligned markets

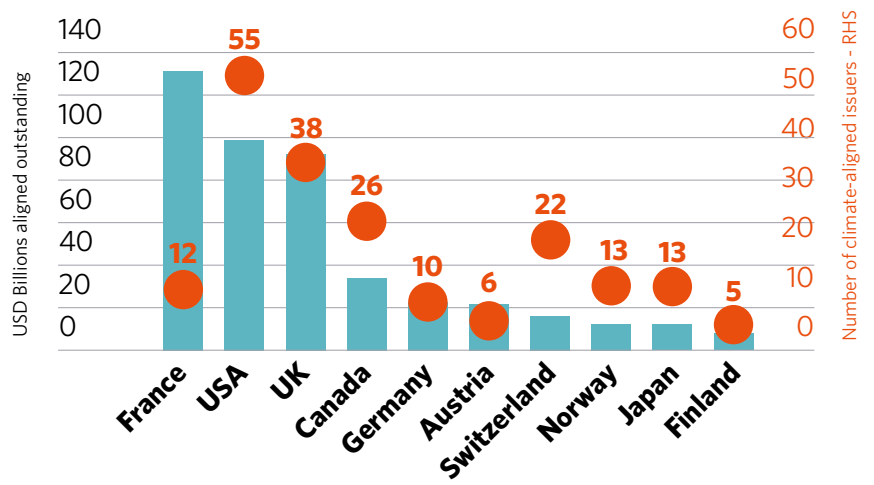

Transport, energy and water amongst Top 3 DM climate-aligned sectors

\begin{tabular}{|l|l|r|r|r|l|}
\hline Rank & $\begin{array}{l}\text { Climate-aligned } \\
\text { sector }\end{array}$ & $\begin{array}{l}\text { USD aligned } \\
\text { outstanding }\end{array}$ & $\begin{array}{l}\text { \% of DM climate- } \\
\text { aligned market }\end{array}$ & $\begin{array}{l}\text { Climate-aligned } \\
\text { issuers }\end{array}$ & Largest issuer(s) \\
\hline 1 & Transport & $257 \mathrm{bn}$ & $53 \%$ & 64 & SNCF, Network Rail, Deutsche Bahn \\
\hline 2 & Energy & $128 \mathrm{bn}$ & $26 \%$ & 108 & EDF, Hydro-Québec, NextEra Energy \\
\hline 3 & Water & $68 \mathrm{bn}$ & $14 \%$ & 33 & Suez, Veolia, Thames Water \\
\hline 4 & Land use & $29 \mathrm{bn}$ & $6 \%$ & 31 & International Paper, WestRock, Mondi \\
\hline 5 & Waste & $4 \mathrm{bn}$ & $1 \%$ & 10 & Covanta \\
\hline 6 & Buildings & $2 \mathrm{bn}$ & $<1 \%$ & 7 & Norbord \\
\hline
\end{tabular}

*Note: All data as of mid-2018. USD figures rounded to $1 \mathrm{bn}$ 


\section{Emerging markets in 2018: A big leap forward in Asia-Pacific}

Climate change and consequent environmental disasters pose significant threats to developing countries. The shift to sustainable systems, climate-resilient infrastructure and the delivery on sustainable development goals (SDGs) are recognised as an imperative and part of the transition to a low-carbon economy.

Green bonds have proven to be an effective financial instrument to finance low-carbon assets. Historically, most green bonds have been used to finance climate-change mitigation measures such as investment in renewable energy to reduce the use of fossil fuels for power generation, low-carbon buildings and clean transport.

Over the last two years, the financing of climate-change adaptation and resilience projects has also gained increased attention, particularly as the incidence of extreme weather events and related disasters have highlighted the vulnerability to flooding, wildfires and droughts. Research into the financial implications of such climaterelated risks points to economic vulnerabilities, too. ${ }^{26}$

\section{Issuance from emerging markets has gained traction}

The first emerging market (EM) green bonds were issued in South Africa in 2012. EM green bond issuance now accounts for about a quarter of total issuance to date. Emerging markets are identified according to $\mathrm{MSCl}^{\prime}$ c classification throughout this report.

China's entry in 2016 and push in 2017 boosted overall EM issuance. China has the largest green bond market and accounts for over $70 \%$ of the total EM issuance to date, and about the same in 2018.

Issuance from other EM countries remains fairly small compared to global volume. However, the number of new issuers entering the market has increased over the past five years. It reached 85 debut issuers in 2018 or $42 \%$ of the global total, which is a significant achievement given the relatively small size of most EM bond markets.

\section{Asia-Pacific market growth underpinned by adoption of green bond guidelines}

Green bonds have gained momentum with the wide uptake of capital markets regulations on green bond issuance. This is particularly evident in EM countries from Asia.

China's Green Bond Guidelines, published by the People's Bank of China (PBoC) in 2015, were amongst the first guidelines to be released with the objective of improving market integrity. The PBoC released the Green Bond Endorsed Project Catalogue - a comprehensive official list of the types of projects eligible for financing via green bonds - to be used by financial institutions, while the NDRC released guidance for non-financial issuers. A series of measures implemented since then to stimulate market growth have supported green bond issuance in China.

China accounts for $18 \%$ of total global issuance and is the second largest market of 2018 with over USD30bn of issuance. More analysis is available in our China Green Bond Market 2018 report. ${ }^{27}$

India has the second largest EM green bond market, with a total of USD7.2bn issued to date. A number of government agencies have contributed significantly to issuance, among them the Indian Renewable Energy Development Agency (IREDA) and the Indian Railway Finance Corporate (IRFC). In 2018, the State Bank of India entered the market with a USD650m Certified Climate Bond, the first of a USD3bn issuance programme. For more analysis see our India Country Briefing. ${ }^{28}$
Issuance from emerging markets gains momentum

200

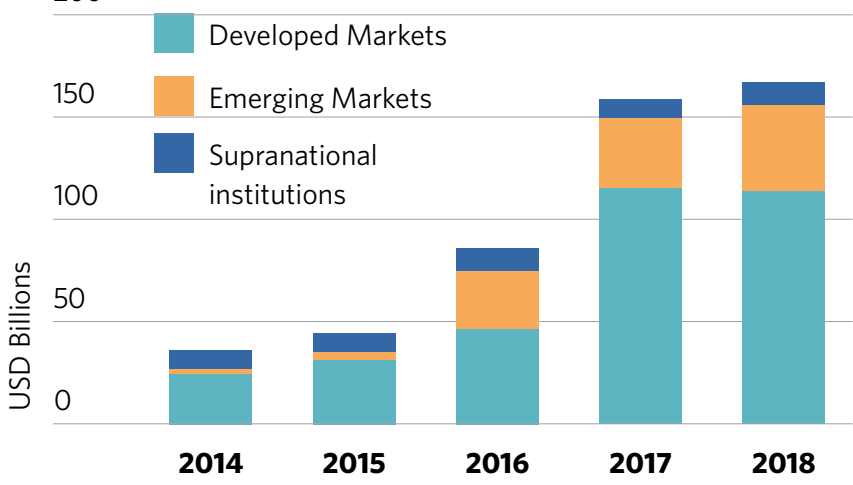

85 new EM green bond issuers debuted in 2018

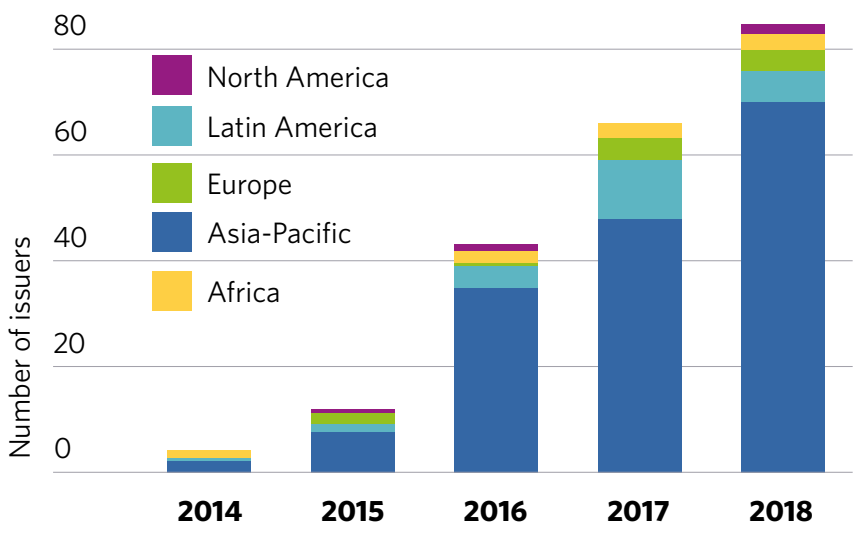

Asia-Pacific dominates EM green bond issuance

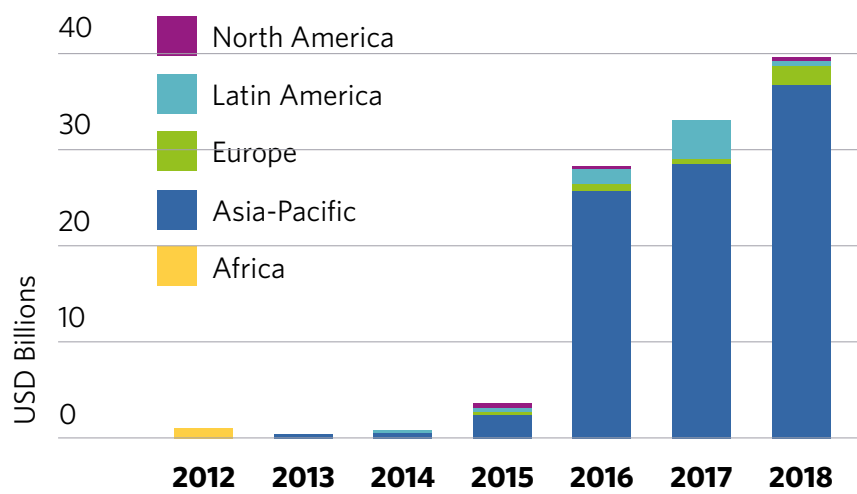

Chinese issuance topped USD30bn in 2018

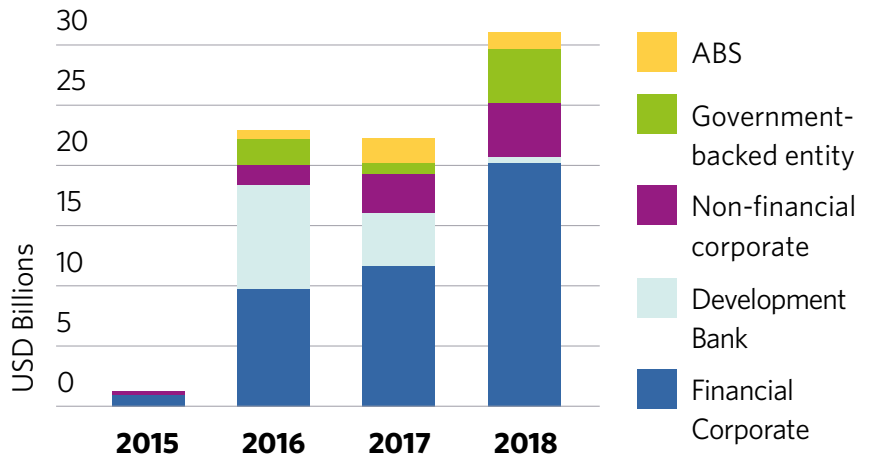


In 2017, the Securities and Exchange Board of India (SEBI) released the Disclosure Requirements for Issuance and Listing of Green Debt Securities, which sets guidelines for issuing green bonds. To support the development of a green bond market, the India Green Bond Council was established by the Federation of Indian Chambers of Commerce and Industry ( $\mathrm{FICCl}$ ) with the support of Climate Bonds Initiative.

In the ASEAN region, the ASEAN Green Bond Standards (AGBS) catalysed green bond issuance in 2018. The momentum has carried over into 2019, with one new issuer from the Philippines becoming a repeat issuer in short order and The Republic of Indonesia coming to market with a second sovereign sukuk.

ASEAN is an association of 10 countries and six of them have seen green bond issuance: Indonesia, Malaysia, the Philippines, Singapore, Thailand and Vietnam. AGBS is supported by the ASEAN Capital Markets Forum, a cooperation platform for the ten financial sector regulators, and provides a common framework for green bond issuance, which should facilitate market transparency.

The world's first green sukuk was issued from Malaysia's Tadau Energy (MYR250m/USD58m), and the first green sovereign sukuk by the Republic of Indonesia (USD1.25bn).

Indonesia has the largest green bond market in ASEAN, with 39\% of total regional issuance. Singapore and Malaysia follow with shares of $35 \%$ and $19 \%$ respectively. Issuance from the 6 ASEAN markets is dominated by non-financial corporates (30\% of the regional total). More analysis is available in our ASEAN Green Finance State of the Market 2018 report. $^{29}$

The region has also seen issuance from the Middle East, Taiwan, South Korea and the Island nations of Fiji and Seychelles.

South Korea entered the green bond market in 2013, with the first issuance coming from the state development bank Export-Import Bank of Korea, as covered in our Korea report. ${ }^{31}$ Development bank issuance dominates the green bond market, with cumulative issuance from both the Export-Import Bank of Korea and the Development Bank of Korea accounting for almost $50 \%$ of total volumes (USD3.8bn). Korea Hydro \& Nuclear Power is the second largest issuer in the country, having issued a total of USD600m.

Taiwan entered the market in 2014, and USD1.2bn worth of green bonds have been placed by Taiwanese issuers since then. Nonfinancial corporates dominate in terms of cumulative volumes, accounting for almost $80 \%$ of total issuance.

Green bond issuance from the Middle East is very limited, with only two deals in the United Arab Emirates and Lebanon. The National Bank of Abu Dhabi issued a USD587m bond in 2017, while Lebanese Fransabank SAL sold its first green bond (USD60m) as a private placement to IFC and EBRD to raise funds for lending on renewable energy, energy efficiency and green buildings.

Island nations Fiji and Seychelles have both issued a sovereign green bond, with the Republic of Seychelles coming to market with the first sovereign blue bond. A blue bond finances projects that support marine reserves and sustainable fisheries, which also classify as green assets. These two issuances are particularly significant for island nations as they are particularly exposed to longer-term climate-related risks, such as rising sea levels and extreme weather. ${ }^{32}$

\section{Soft 2018 but high potential in Latin America}

Issuance from Latin America and the Caribbean (LAC) slowed down in 2018 compared to a record-breaking 2017, mainly due to lower issuance from Brazil. Brazilian issuers contributed over $60 \%$ of total
In India, State Bank of India debuted in 2018

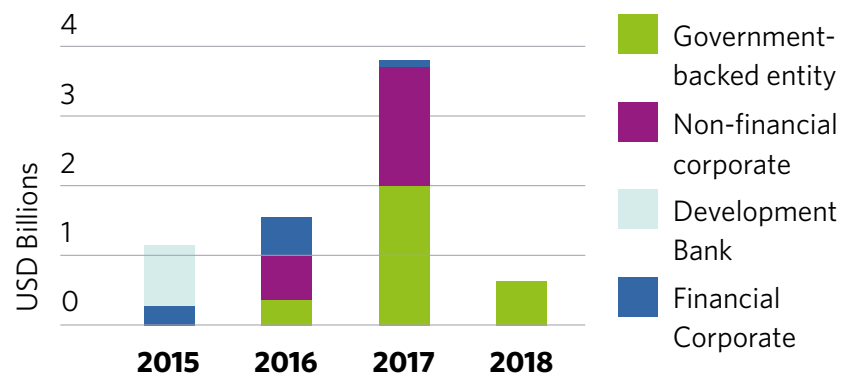

Asia-Pacific issuance (ex China) has remained strong

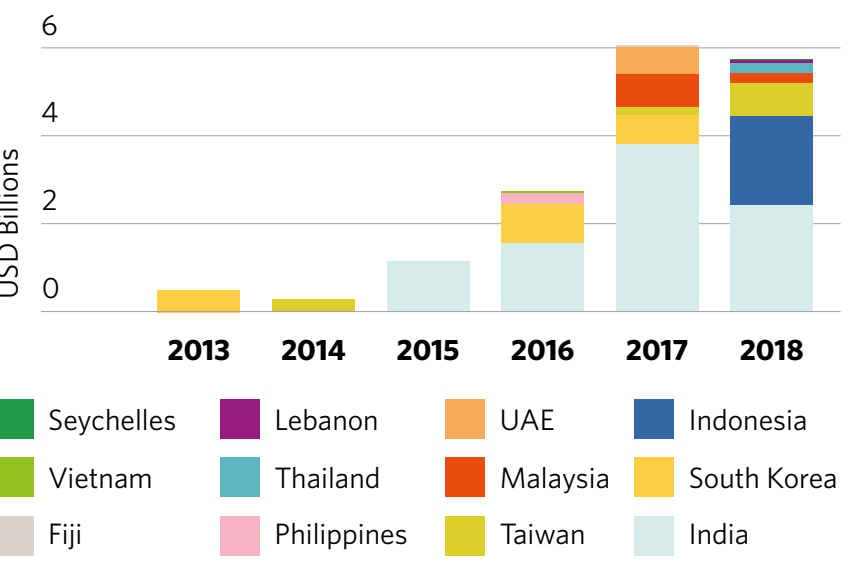

ASEAN Green Bond Standards are aligned with the four core components of the Green Bond Principles. ${ }^{30}$ The key additional features of the ASEAN GBS include:

- eligible issuers must have a geographical or economic connection to the region

- fossil fuel power generation projects are excluded

- continuous accessibility to information for investors

- more frequent reporting is encouraged

- external review providers are expected to demonstrate relevant expertise (external reviews are voluntary)

\section{ASEAN issuance surged in 2018}

3

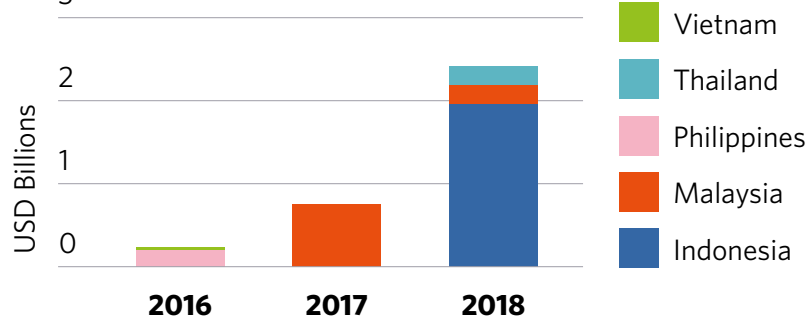

30 Certified Climate Bonds from Asian EM issuers

\begin{tabular}{|l|r|r|l|}
\hline Country & Bonds & $\begin{array}{r}\text { Amount } \\
\text { (USD m) }\end{array}$ & Criteria \\
\hline India & 14 & 3,852 & $\begin{array}{l}\text { Solar, Wind, Low Carbon } \\
\text { Transport, Low Carbon Buildings }\end{array}$ \\
\hline China & 16 & 10,499 & All \\
\hline Philippines & 1 & 226 & Geothermal \\
\hline Thailand & 1 & 153 & Solar \\
\hline
\end{tabular}

Note: Data as of 31 December 2018. Two issues were Certified in the Phillippines in 2019 (see page 17). 
LAC issuance in 2017, but green bond issuance volumes were much lower last year, perhaps due to the climate of uncertainty around the 2018 Brazilian general elections.

2018 has, on the other hand, witnessed a debut deal from Uruguay: Atlas Renewable Energy issued a USD108.2m two-tranche green private placement. There were also new issuers from Peru, Chile, Colombia and Brazil.

While not included in Latin America but North America figures, a 2018 deal from Mexican state-backed entity FIRA is worth highlighting. FIRA is an agriculture financing agency and it issued the first Certified Climate Bond to exclusively finance protected agriculture projects. The MXN2.5bn (USD130m) green bond sets the landscape for a new market to foster the expansion of more sustainable agriculture practices across Latin America.

Finally, the development of green bond guidelines by the Santiago and Lima stock exchanges in 2018 aims to promote and facilitate green bond issuance in Chile and Peru.

\section{European EM issuance set a record in 2018}

Poland was the first country to issue a sovereign green bond in December 2016, and it issued a second sovereign green bond in February 2018. As of the time of writing, Poland had issued EUR1.7bn (USD2bn) and was in the market with a further EUR2bn green bond. This sends a strong signal to the market about the country's ambition towards meeting its decarbonisation strategy.

Issuance from Central and Eastern Europe also came from the Baltics and Slovenia. Lithuania placed the first tranche (EUR20m, USD24m) of its sovereign green bond programme with proceeds earmarked for energy efficiency upgrades to around 160 apartment buildings. State-backed Lietuvos Energija issued its first green bond in 2017, becoming a repeat issuer in 2018 (cumulative: USD695m). Proceeds from both transactions have been allocated across a number of sectors, including renewable energy, low-carbon buildings and waste.

Slovenia's SID Bank, a national development bank, entered the market in 2018. According to the green bond framework, proceeds were allocated across a wide range of sectors, including renewable energy, buildings and transport, where all fossil fuel-based assets are specifically excluded. It is the second Slovenian entity to issue green bonds, after private utility company Gen-I-Sonce in 2017.

2018 also witnessed the first issuance from Iceland. National utility company Landsvirkjun issuing a USD200m bond to finance renewable energy projects. The city of Reykjavik followed suit later in the year, issuing ISK4.1bn (USD33m). 2019 started with a new issuer, Reykjavik Energy, entering the market with a ISK3.5bn (USD25m) deal. The green bond is listed on the Nasdaq Iceland Sustainable Bond market and will finance an array of renewable energy related projects, including carbon capture at its geothermal plant.

\section{Green bonds in emerging markets - an overview}

This section provides an overview of green bond issuance in emerging markets. China, however, is excluded from this overview. As it accounts for more than $70 \%$ of EM green bond issuance, Chinese deals crowd out smaller markets and skew figures. For more details on the green bond market in China, please see our latest China report. ${ }^{27} \mathrm{Here}$, we analyse the rest of the EM market.

\section{Non-financial corporates are the most popular issuer type}

Issuance of green bonds in emerging markets comes from a welldiversified set of issuers. A total of 206 entities have entered the market, with 85 debut issuers in 2018.

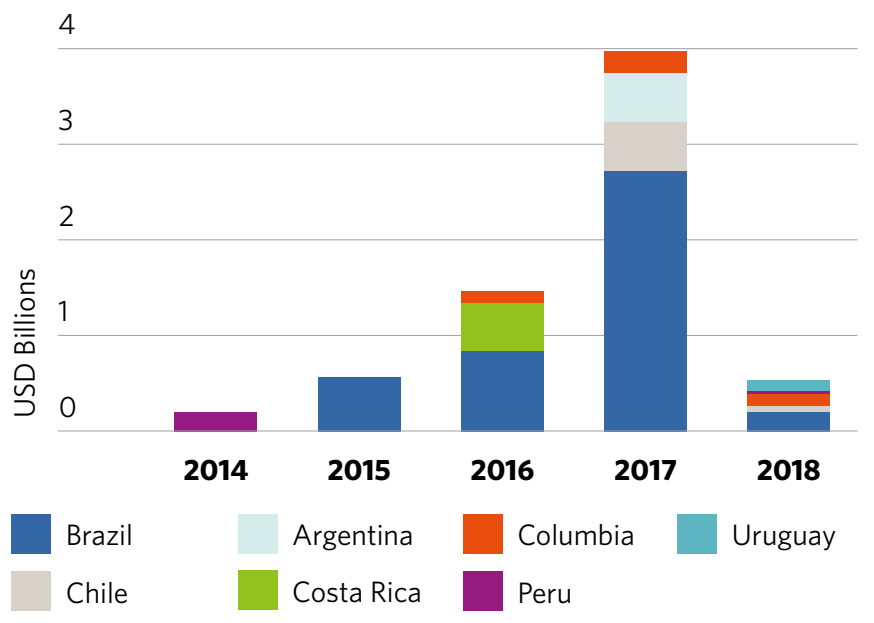

Europe EM green bond issuance set a record in 2018

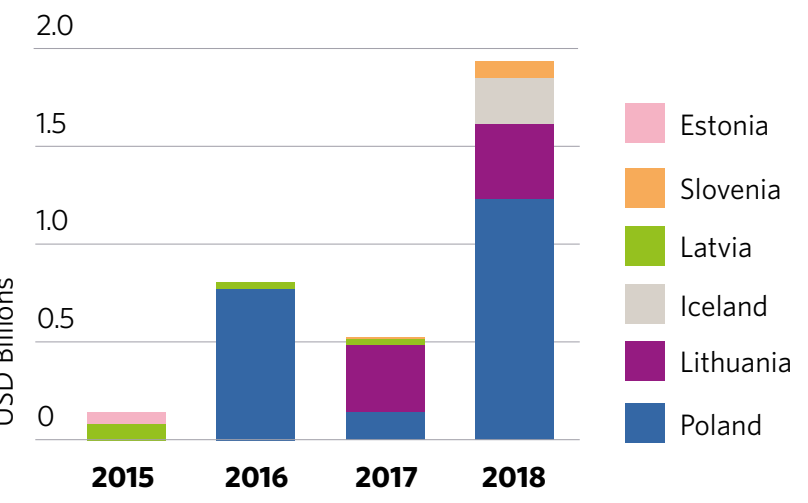

Top 10 EM issuers (cumulative 2012-2018, ex-China)

\begin{tabular}{|c|c|c|c|c|}
\hline Issuer & Country & Issues & $\begin{array}{l}\text { Amount } \\
\text { (USDm) }\end{array}$ & $\begin{array}{l}\text { Sector(s) } \\
\text { funded }\end{array}$ \\
\hline $\begin{array}{l}\text { Republic of } \\
\text { Poland }\end{array}$ & Poland & 2 & 2,023 & $\begin{array}{l}\text { Energy, buildings, } \\
\text { land use }\end{array}$ \\
\hline $\begin{array}{l}\text { Greenko } \\
\text { Investment co }\end{array}$ & India & 2 & 1,500 & Energy \\
\hline $\begin{array}{l}\text { Export-Import } \\
\text { Bank of Korea }\end{array}$ & Korea & 4 & 1,350 & $\begin{array}{l}\text { Energy, buildings, } \\
\text { transport, water, } \\
\text { waste, industry }\end{array}$ \\
\hline $\begin{array}{l}\text { Republic of } \\
\text { Indonesia }\end{array}$ & Indonesia & 1 & 1,250 & $\begin{array}{l}\text { Energy, buildings, } \\
\text { transport, waste, } \\
\text { land use }\end{array}$ \\
\hline $\begin{array}{l}\text { Suzano Papel } \\
\text { e Celulose }\end{array}$ & Brazil & 4 & 1,195 & $\begin{array}{l}\text { Energy, buildings, } \\
\text { water, land use }\end{array}$ \\
\hline BNDES & Brazil & 1 & 1,000 & Energy \\
\hline Fibria & Brazil & 1 & 700 & $\begin{array}{l}\text { Energy, water, } \\
\text { waste, land use }\end{array}$ \\
\hline $\begin{array}{l}\text { Lietuvos } \\
\text { Energija }\end{array}$ & Lithuania & 2 & 695 & $\begin{array}{l}\text { Energy, transport, } \\
\text { waste }\end{array}$ \\
\hline IREDA & India & 6 & 651 & Energy \\
\hline $\begin{array}{l}\text { Industrial } \\
\text { Development } \\
\text { Corporation }\end{array}$ & $\begin{array}{l}\text { South } \\
\text { Africa }\end{array}$ & 1 & 651 & Buildings \\
\hline
\end{tabular}


Non-financial corporates dominate the market, having issued a third of the total volumes, as of year-end 2018. Almost half the issuers came from the energy sector, followed by forestry and paper companies ( $27 \%$ of cumulative issuance). The rest came from industry, property and transport companies.

Government-backed entities, local governments and sovereigns account for almost $40 \%$ of cumulative issuance. To date, six EM countries have issued sovereign green bonds, for a total of USD3.4bn. The Republic of Seychelles issued the first sovereign blue bond (USD15m) in 2018, while Indonesia issued the first green sovereign sukuk (USD1.25bn). Nigeria was the first, and so far only, African state to issue a sovereign green bond (USD30m).

Proceeds from sovereign green bonds have been primarily earmarked to finance renewable energy, transport and land use, each representing $25 \%$ of the total share. Adaptation and buildings follow with $10 \%$ each, while waste takes $5 \%$ of the total share. Sovereigns have earmarked a higher share of proceeds towards adaptation compared to other issuer types in EM, with the Republic of Indonesia and the Republic of Fiji allocating a total of USD321m. Investing towards adaptation is particularly significant in EM as developing countries are exposed to higher climate-related risks, and hopefully 2019 will see an increase towards the sector.

After non-financial corporates, government-backed entities are the second most common issuer type in EM, representing $22 \%$ of the total share. The top five issuers are Lietuvos Energija (Lithuania), IREDA (India), the State Bank of India, Korea Hydro \& Nuclear Power and the National Bank of Abu Dhabi.

Development banks also represent a significant share of the market, having contributed almost $20 \%$ of EM issuance. BNDES (Brazil), Export-Import Bank of Korea, NAFIN (Mexico), Korea Development Bank and Banco Nacional de Costa Rica are the top 5 development banks, having issued a cumulative volume of USD3.5bn.

Financial corporates account for $10 \%$ of the market. Issuance mainly comes from commercial banks, with Axis Bank (India), Nedbank (South Africa), Yes Bank (India), Bancolombia (Colombia) and E Sun Commercial Bank (Taiwan) representing the top 5 issuers. Commercial banks contributed USD2.7bn to the green bond market.

$A B S$ issuance in emerging markets (excluding China) remains very limited: one Agricultural Credit Rights (CRA) deal from Brazilian company Suzano Papel e Celulose. CRA deals are popular in Brazil, so we would expect to see at least more of these ABS deals. ${ }^{33}$

\section{Clean energy dominates green bond allocations}

EM issuers have allocated green bond proceeds to finance primarily renewable energy, with $52 \%$ of total proceeds earmarked for such investments. Allocations to low-carbon buildings are a distant second with $13 \%$, while transport ranks third with $11 \%$.

Sustainable land use is a key sector with $10 \%$ of total allocations and has gained particular importance over the last two years due to issuance from the certified pulp \& paper industry in Brazil. Indonesian joint venture TLFF I became the first issuer to finance sustainable agriculture in early 2018 with a bond that used the blended finance approach - i.e. combining public and private sector funding - to finance sustainable rubber plantations on heavily degraded land in two provinces in Indonesia, as well as afforestation and biodiversity conservation measures, and smallholder plots.

The first sovereign blue bond, issued by the Republic of Seychelles, is a landmark deal. The bond, designed to finance sustainable marine and fisheries projects, is partially guaranteed by a USD5m
Non-financial corporates generated a third of total volume

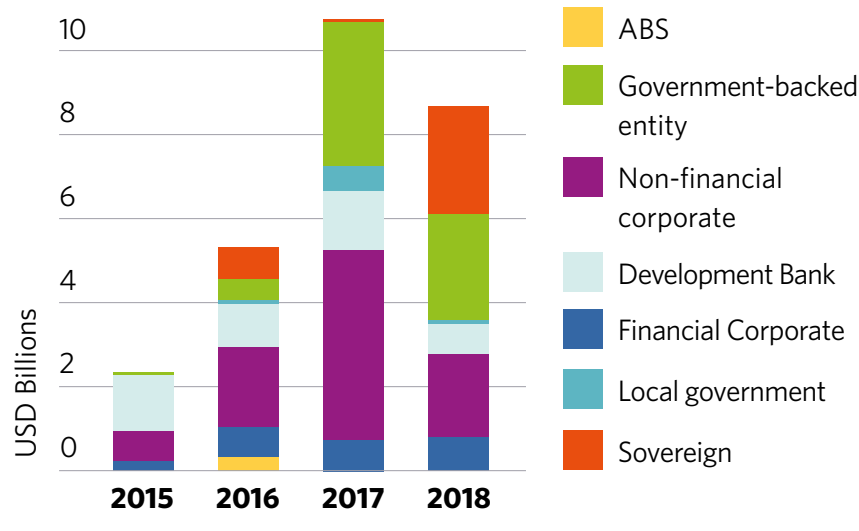

Sovereign green bonds finance mainly renewable energy, land use and transport

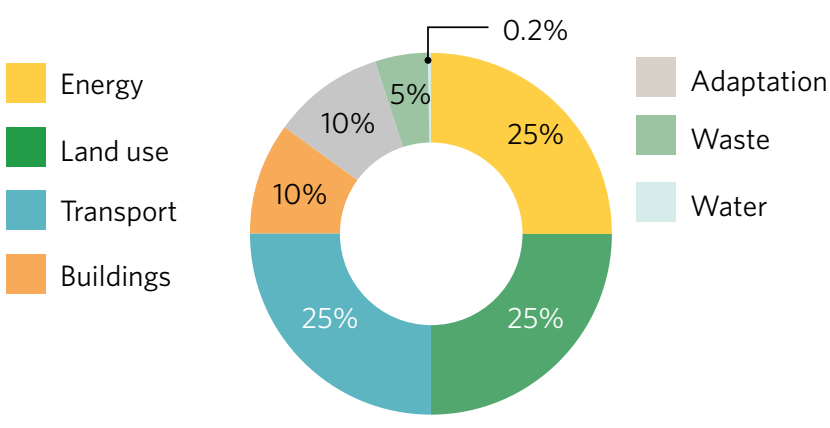

National development banks are instrumental in kickstarting green bond markets

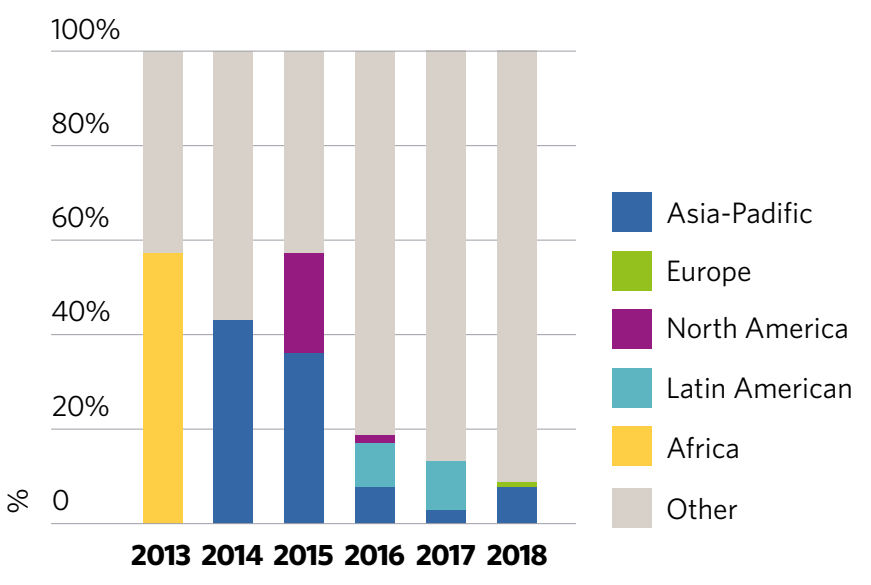

More than half of green bond proceeds are earmarked for energy projects

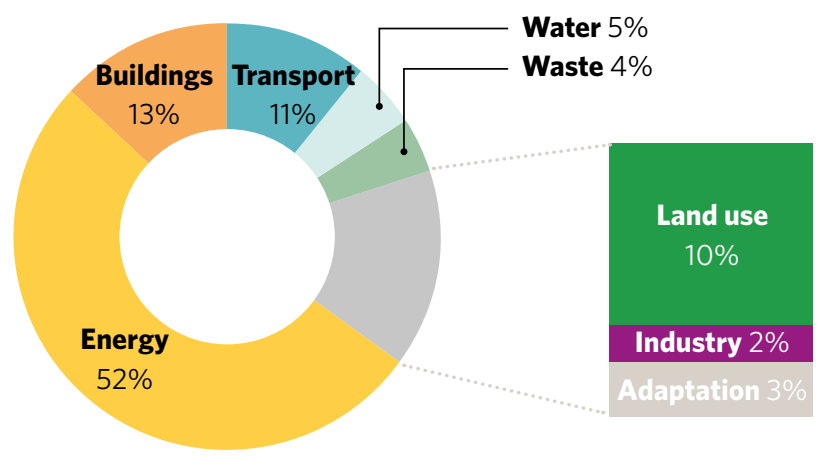


guarantee from the Work Bank (IBRD) and supported further by a USD5m concessional loan from GEF. The World Bank assisted in the development of the bond, which also attracted international investors, demonstrating the potential to harness capital markets to finance the sustainable use of marine resources.

Albeit currently much smaller than energy, sustainable agriculture, forestry and fisheries are key sectors for many emerging markets.

\section{External reviews are popular with EM issuers}

Three quarters of EM green bonds by volume have at least one external review, of which $60 \%$ benefit from a second party opinion (SPO). In terms of issuance by number, $80 \%$ of deals benefit from at least one external review. The most popular SPO provider is Sustainalytics, having reviewed just below $35 \%$ of the deals, followed by CICERO (16\%) and Vigeo Eiris (5\%).

Around 15\% (USD4.5bn) of bonds obtained a green bond rating. Moody's is the most popular rating agency, having provided Green Bond Assessments on $90 \%$ of rated deal volume. S\&P and RAM Holdings (Malaysia) follow with a very small share, $1 \%$ and $0.6 \%$ respectively. Five of the rated issuances have also obtained an SPO. These include both sovereign issuances from Poland, K-Water (South Korea) and Latvenergo As (Latvia).

Certification under the Climate Bonds Standard ensures that assets or projects financed by the verified green bond are compliant with the Paris Agreement. As of the end of 2018, excluding China, $18 \%$ of EM green bond volume had been certified under the Climate Bonds Standard and Certification Scheme. The uptake of Certification in emerging markets (ex-China) is higher than the global average (14\% for 2018), and India is home to the highest share of Certified Climate Bonds (USD3.9bn) in emerging markets (after China: USD10.5bn).

\section{Over half of EM deals by volume have both use-of- proceeds and impact reporting}

Emerging markets are often associated with lack of transparency. However, this is not the case for green bonds. CBI's study on Postissuance reporting in the green bond market (see Spotlight on page 9) shows that for EM deals issued prior to November 2017, $91 \%$ of green bond deals by amount issued had reporting in place, with China included in the figures.

Excluding China, $86 \%$ of EM deals by amount issued have postissuance reporting in place, and $54 \%$ have both use-of-proceeds (UoP) and impact reporting. In fact, $58 \%$ of deals (by amount issued) for which there was no commitment to report at issuance, did in fact report. For deals where issuers only promised to report on use of proceeds, $43 \%$ of deals by amount issued have both UoP and impact reporting in place. This is all positive for building market credibility.

The term reporting is defined as publicly available post-issuance information on allocation of proceeds and/or environmental impacts, and loans are excluded. Figures may underestimate reporting levels, as in private placement deals reporting is often only to the investors.

\section{Tenors up to 5 years dominate EM green bonds}

More than $45 \%$ of issuance has a tenor of up to 5 years, followed by around $40 \%$ of bonds with a tenor of 10 years or less. Only a small share of the issuance has a tenor above 10 years. Green bonds with up to 5-year tenors are popular across different issuer types, but are particularly favoured by financial institutions. This is in line with global trends.

Non-financial corporates, on the other hand, seem to prefer slightly longer bond tenors. This is likely attributable to the long-term nature

\section{Sustainalytics is the largest SPO provider}

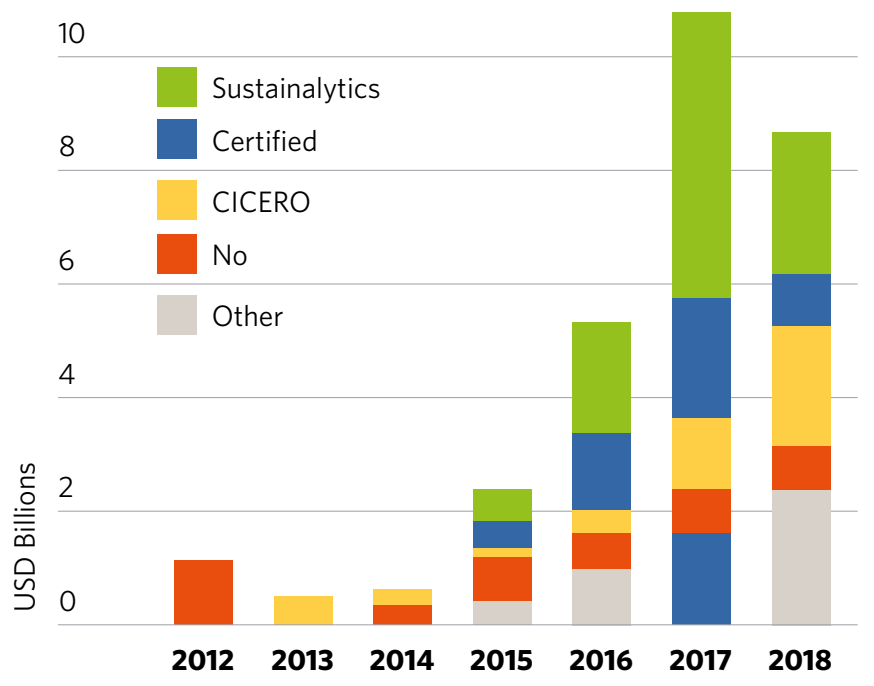

\section{$86 \%$ of EM deals have post-issuance reporting}

12

Post-issuance UoP and impact reporting

9

Post-issuance impact reporting

Post-issuance UoP reporting

No post-issuance reporting

6

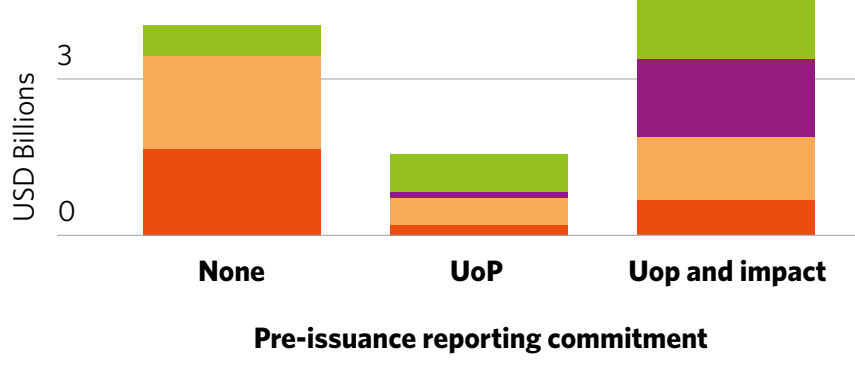

More than $45 \%$ of issuance has up to 5-year tenor

Up to $5 Y$

5-10Y

10-20Y

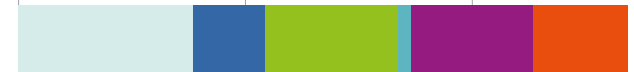

$<20 Y$

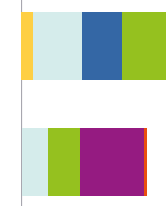

N/A

USD

Billions 0

5

10

15 
of the assets they finance. However, in many countries it is local governments, government-backed entities and sovereigns that have the longest-dated bonds.

\section{Over half of EM issuance is benchmark-sized}

Deals falling in the USD100-500m and USD500m-1bn size buckets account for $38 \%$ each of total issuance. Only $9 \%$ of deals are of up to USD100m, while 15\% deals were sized at USD1bn or more.

On average, bond size tends to be smaller in emerging markets compared to developed countries, with a median value of USD108m for EM. However, deals of USD1bn+ started appearing in 2017 and have increased by $25 \%$ in 2018 , which has pushed the average deal size up. This trend of larger bond sizes has been developing in both emerging and developed markets, and it suggests rising investor acceptance. It is particularly positive to see it in EM countries.

\section{Almost 75\% of EM issuance is in USD or EUR}

Green bond issuance in EM is dominated by hard currencies, perhaps, as an attempt to attract international investments. Sovereign green bonds are primarily issued in USD and EUR, except for Nigeria and Fiji, which issued in local currency. Development banks and government-backed entities have also issued in hard currencies, while the only ABS issuance from Brazil was issued in BRL as it targeted domestic investors.

Financial corporates also most often denominate their green bonds in US dollars. However, there is also issuance in South African Rand and Colombian Peso. Issuance in local currency indicates domestic demand, which in turn is supportive of green lending to the wider borrower universe. This includes smaller companies for whom it may be uneconomical to access the debt capital markets directly.

\section{Multilateral development banks support issuers}

In many cases, local banks issue in USD in the context of private placements with multilateral development banks. In June 2018 TMB Bank became the first Thai commercial bank to issue a green bond (USD60m). The bond was sold as a private placement to IFC. TMB Bank is aiming to increase its green lending portfolio from THB9bn to THB15bn by 2023 with the support of IFC, and to issue further green bonds to attract international investors. Similarly, Lebanese Fransabank SAL placed its USD60m green bond with IFC and EBRD.

In 2019, AC Energy (Philippines) issued two Certified Climate Bonds of USD225m and USD185m respectively. The first transaction was supported by the IFC with an anchor investment of USD75 $\mathrm{m}$ to support the public placement. The second was a private placement, with ADB acting as one of the main investors with USD2Om.

Supranationals also support local-currency issuance. In 2015, for instance, IFC issued a masala green bond to finance the investment in a domestic green bond issuance from Indian Yes Bank.

\section{Green Bonds are structurally diverse in EM too}

Last but not least, emerging markets have witnessed increased diversification in green bond structures. Unsecured bonds are the most common bond type, representing $33 \%$ of total volumes. However, at 26\% each, sukuk issuance from Malaysia and Indonesia and private placements are also quite common. Both the Seychelles and Fiji sovereign deals, as well as many EM bank issuers have used private placements. The use of diverse structures underscores the ability to adopt and adapt the "green" label to local market circumstances and investor appetite.
Over half of EM issuance is benchmark-sized

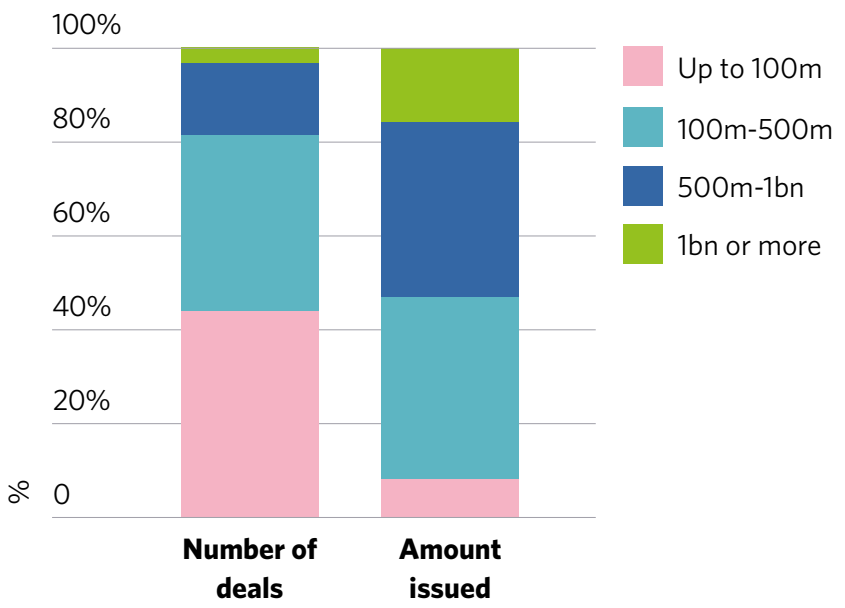

Most EM deals are denominated in USD or EUR

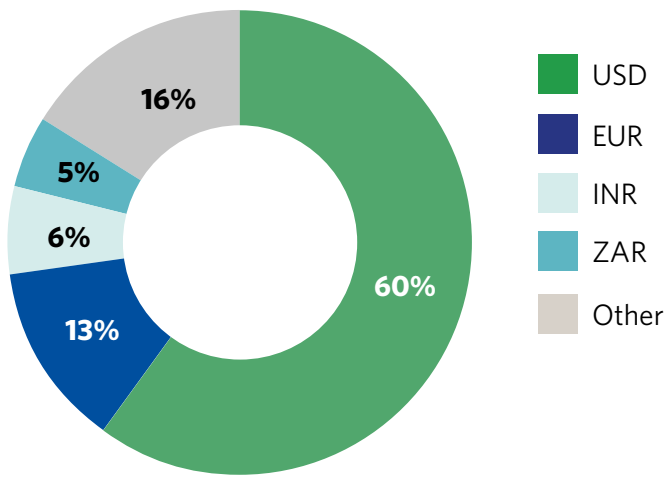

USD denominates development bank and financial corporate issuance

1bn or more

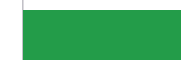

500m-1bn

$100 m-500 m$

Up to $100 m$

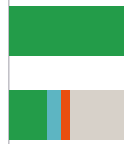

USD Billions

0

4

\section{Green bond issuance in EM is structurally diverse}

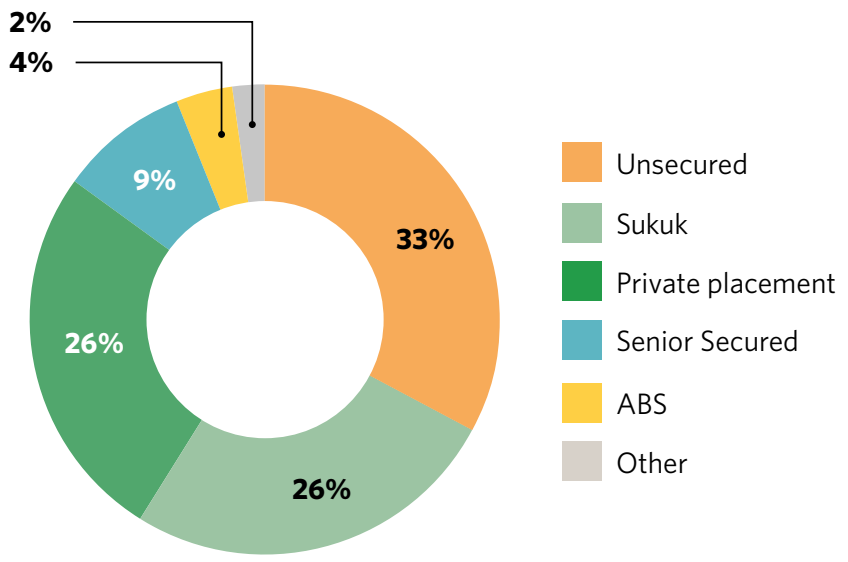




\section{The role of financial institutions: lend, underwrite, create new products, issue bonds and support}

Financial institutions are integral to the market. Their green bond issuance is only part of the story. As structuring agents and underwriters, they actively support issuers in coming to market. Asset managers and stock exchanges provide the means to raise funding from investors.

\section{Financial institutions as active green bond issuers}

Green bond issuance from global financial institutions passed the USD100bn mark in 2018. South African Nedbank entered the market in August 2012 with a green retail offering. Since then, a variety of institutions have issued green bonds: 127 as of end-2018.

Most issuance has been senior unsecured. Covered bonds are the second most issued bond type. Crédit Agricole CIB used a synthetic $A B S$ to transfer risk of a mixed loan portfolio (including green project finance) and create capital capacity for green lending .

Early issuance from financial institutions was more varied in the allocation of proceeds. The mix has shifted to feature an evergreater share of property financing. Banks have used mainly senior unsecured bonds to fund mortgage lending programmes for energy efficient homes (ABN AMRO, Barclays) and commercial properties (BerlinHyp, LBBW), but also RMBS (Obvion, NAB) and covered bonds with cover pools of commercial property (BerlinHyp, Deutsche Hypo) or housing (SpareBank 1, DNB Boligkreditt).

China is in pole position for financial corporate green bond issuance as the top 5 issuing entities are Chinese! Industrial Bank has already raised a whopping USD10bn in green bonds, followed by Bank of China (USD6.4bn) and Bank of Beijing (USD4.5bn).

2018 financial corporate issuance more than doubled from 2017, surging from USD22.9bn to USD49.2bn. Commercial banks fuelled the growth. In 2018 alone, 78 institutions issued 102 green bonds, with a median size of USD290m and an average deal size of USD 482m. 65\% of 2018 issuance was in hard currency. Banks in developed markets rarely issue below benchmark size (USD500m+). There are, however, smaller deals, such as debut bonds from local banks in emerging markets (e.g. Thailand, Lebanon, Namibia).

Commercial banks lead financial corporate green bond issuance but there is increasing sectoral diversity. For instance, CPPIB was the first pension fund in the world to issue a green bond in 2018 and closed its second green bond in February 2019. Asset managers such as Canadian Manulife, American Prologis and Australian Investa have also entered the green bond market. This is a welcome move as these entities fund real assets directly, channelling institutional money at scale.

The GLP and the green tagging of loans would facilitate a more targeted green financing approach across sectors. This, in turn, could support further green bond issuance from banks, and hence continued market expansion, with banks acting as aggregators and intermediaries between small borrowers and the capital markets.

\section{Green - a new product range for corporate banking}

Commercial banks now offer green products. In late 2017, Barclays launched a range of green corporate banking products, including loans, deposits, asset finance and innovation finance. ${ }^{34}$ In November 2018, Westpac launched its Green Tailored Deposit scheme for large investors (minimum investment of AUD $1 \mathrm{~m}$ ). ${ }^{35}$ It will finance a pool of wind farm and low-carbon building assets that comply with the Climate Bonds Standard. The product garnered the interest of several municipalities looking for green investment opportunities.

\section{Chinese banks have dominated financial corporates' green bond issuance since 2016}

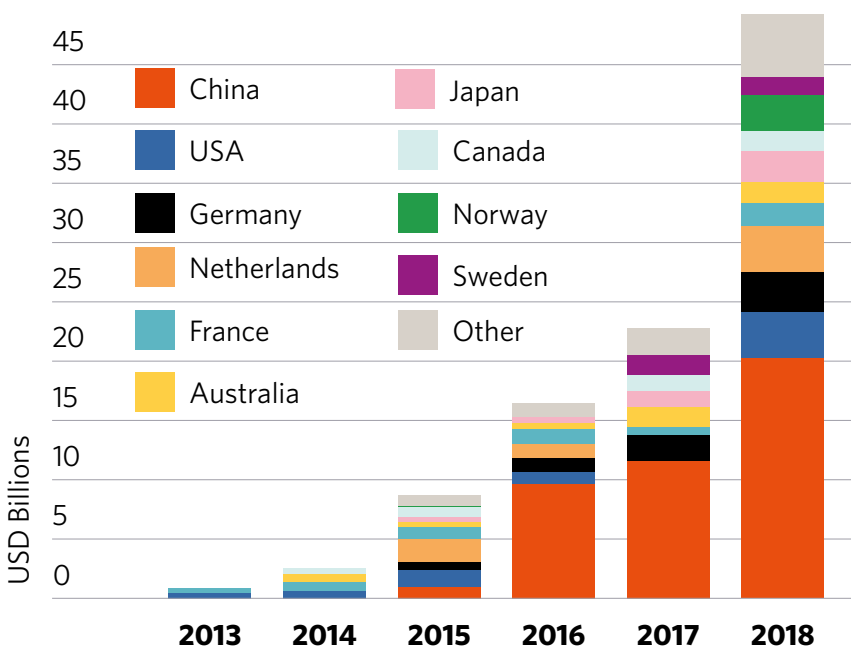

\section{Green investment funds keep increasing}

At the time of writing, almost 50 dedicated green bond funds have been set up, including ten in 2018, to respond to increasing demand from a wide pool of investors. In 2018, Amundi, a global asset manager, set up Amundi Planet - Emerging Green One, a USD2bn green bond fund specifically to invest in issuance from EM financial institutions with the aim of supporting local bond market development. ${ }^{36}$ Local banks, in turn, are expected to engage in green lending across the real economy. In this manner, green bond funds can leverage their impact and facilitate the scaling up of the green finance market.

\section{Green Bond ETFs: there are now four kids on the block}

Exchange Traded Funds (ETF) are funds that trade on exchanges. They offer a liquid and transparent route for investors to gain exposure to financial markets. Transaction costs are low compared with buying the individual exposures. Green ETFs invest in green bonds.

At present, the green bond ETF market is small - due to the limited size of the green bond market - and counts four market entrants:

- Lyxor Green Bond ETF, which is based on the Solactive Green Bond Index, launched at the end of February 2017 with a market cap of just over EUR5m. As of 12 February 2019, that had increased to EUR55m, so it has grown eleven-fold. ${ }^{37}$

- VanEck Vectors Green Bond ETF launched in March 2017 at USD5m and, as of 12 February 2019, had USD25.6m market cap. It only includes bonds identified as green by Climate Bonds and tracks the S\&P Green Bond Select Index..$^{38}$

- iShares Global Green Bond ETF came to market in November 2018 with a market cap of USD25.1m, which has since increased to USD25.7m. The ETF tracks the Bloomberg MSCI Global Green Bond Index. ${ }^{39}$

- UC MSCI European Green Bond EUR UCITS ETF, launched in December 2018, includes EUR-denominated investmentgrade green bonds issued in Europe. The initial market cap was USD20.3m and stands at USD20.1m as of 12 February $2019 .{ }^{40}$

The early entry of these market funds will give them the benefit of track-record and penetration once the green bond market is big enough to support this area of investment on a larger scale. 


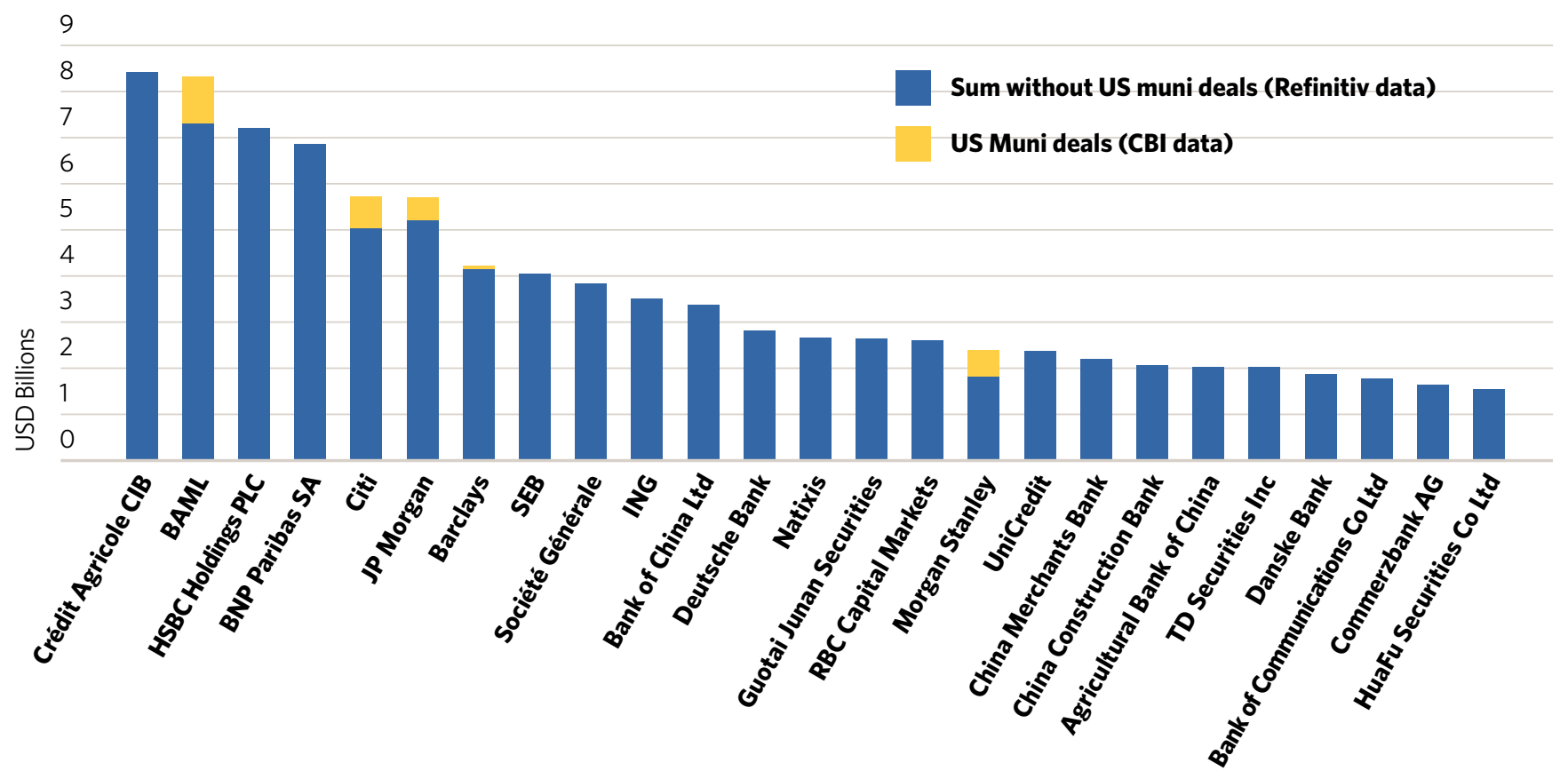

\section{Green bond underwriters actively support issuance}

SEB, one of the top 20 green bond underwriters for 2018, acted as arranger for the World Bank's first green bond in 2009, when the term "green bond" was coined.

Most green bond underwriters are also green bond issuers. Crédit Agricole CIB is the top green bond underwriter of 2018 in the league table compiled jointly by Refinitiv and CBI. The institution is also the 12th largest green bond issuer with over 100 green bonds.

Likewise, Bank of China, the top emerging markets underwriter for 2018 , is a green bond issuer both on the domestic and the offshore market. It has also issued Certified Climate Bonds.

\section{Stock exchanges can provide enhanced visibility}

Stock exchanges with dedicated green or sustainability bond segments increase green bond visibility and their listing requirements promote transparency and market integrity. This supports all investments.

Oslo Børs was the first stock exchange in the world to create a separate list for green bonds. Currently, 15 stock exchanges have dedicated green/sustainability bond segments.

Luxembourg Stock Exchange and the Luxembourg Green Exchange are the largest green bond listing venues. In addition to bonds, the exchange now also lists green bond funds.

\section{Luxembourg Green Exchange was the No.1 green bond trading venue in 2018}

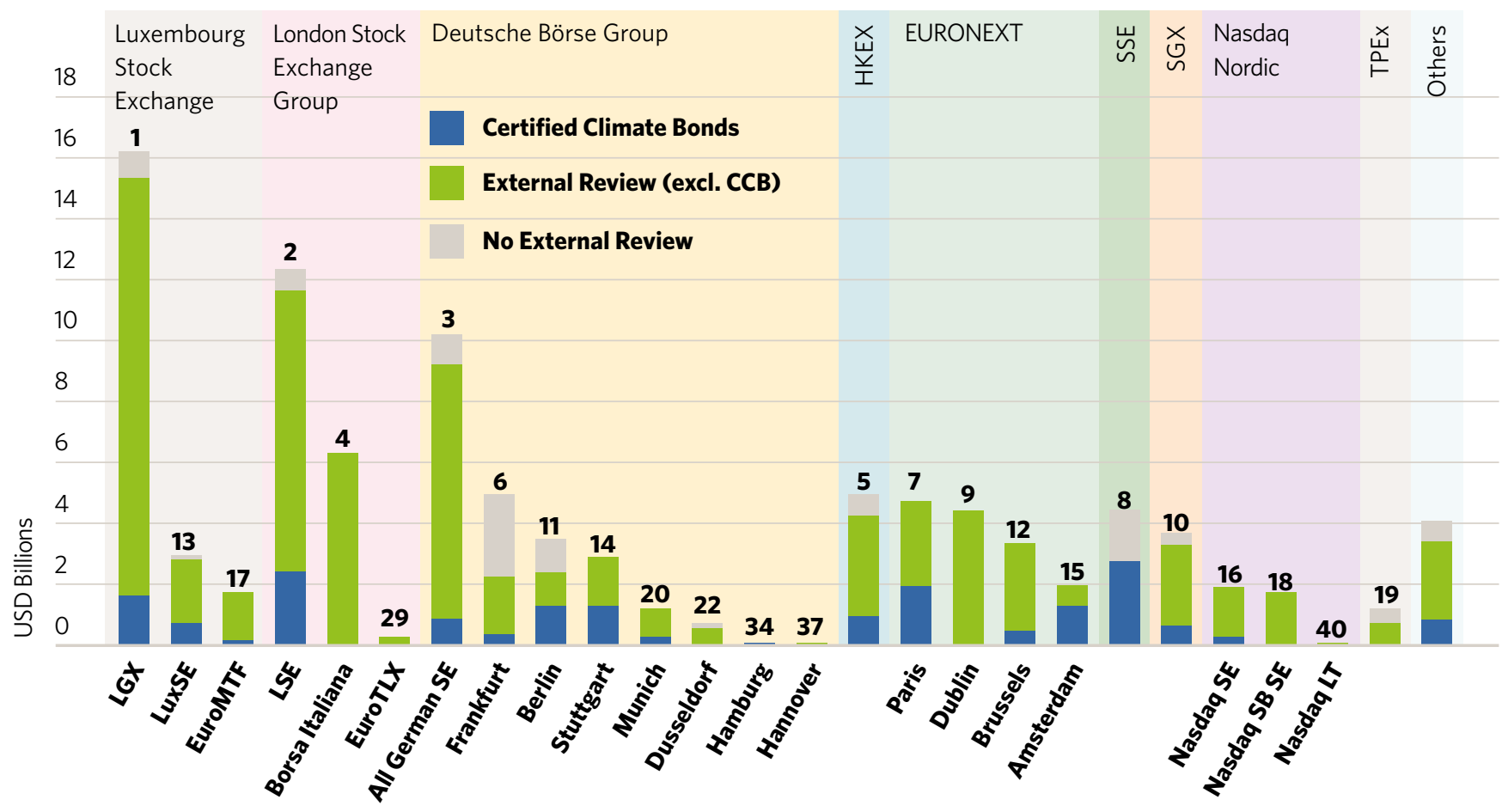




\section{Spotlight on green retail products}

Interest in sustainable investing among retail investors has been increasing steadily in recent years, with millennials taking a leading role in amplifying momentum. ${ }^{41,42}$ As the share of retail assets under management (AuM) grows, retail investors - i.e. individuals rather than institutions - could prove to be a key driver in directing capital flows to green projects, as well as pushing institutional investors to better address climate change risks. ${ }^{43}$

In response to the burgeoning demand for environmentallyconscious investments, the range of green retail products available to both small and large retail investors is expanding.

\section{Retail green bonds}

The retail green bond market has been active for several years, with offerings from a diverse range of issuers and regions.

Canada: CoPower, the country's first online platform for clean energy investing, has issued two retail green bonds backed by a diversified portfolio of loans to clean energy and energy efficiency projects across North America. ${ }^{44}$

Japan: The Uridashi market has featured environmentally-themed bonds for a long time. This suggests strong interest in green investment products among Japanese retail investors. Retail green Uridashi issuers include supranationals, such as the World Bank and the Asian Development Bank, Norway's local government financing agency Kommunalbanken, as well as financial institutions such as Westpac Banking Group (Australia).

New Zealand: Contact Energy's Certified Green Borrowing Programme also includes three retail bonds totalling NZD472m (USD356m). They support geothermal energy generation. ${ }^{45}$

South Africa: Nedbank came to market in 2012 with a ZAR4bn (USD481m) Green Savings Bond. The funds were earmarked for renewable energy projects. The bond was targeted at retail clients by allowing investments from as little as ZAR1,000 (USD122) and with returns guaranteed by the issuer. ${ }^{46}$

United Kingdom: Retail mini-bonds have become popular, with investors showing appetite for deals financing primarily solar and wind projects. Big60Million, now part of Innogy (Germany), issued four Certified Climate Bonds in 2014/15 to refinance the cost of developing and constructing four solar projects. ${ }^{47}$

United States of America: In 2014, SolarCity (now Tesla Energy), best known for its Solar ABS, issued a USD200m retail secured bond, with investments starting at USD1,000. ${ }^{48}$

Other issuers that have tapped into the retail green bond market include US Munis such as the New York Metropolitan Transport Authority (NY) and Bay Area Rapid Transport (CA), local governments such as Auckland Council (New Zealand), and corporates including Advanced SolTech Sweden AB (Sweden).

\section{Crowdfunding platforms}

Crowdfunding has gained traction as a funding model for new ventures in recent years. It is increasingly used to source capital for climate-related projects. Several wellestablished crowdfunding platforms, such as Indiegogo and Kickstarter, support green entrepreneurs by offering dedicated environmentally-themed segments. Other platforms have fully specialised in green ventures, with renewable energy being a popular area of focus. ${ }^{49,50}$
California-based Mosaic is an interesting case of a company which has evolved its business model. It commenced operations in 2011 as a crowdfunding platform to allow investors to fund community solar projects. ${ }^{51}$ In 2014, it started offering residential solar loans, and later expanded to include home batteries and energy efficiency upgrades. Mosaic has capitalized on the green securitization market to refinance its loans, and has closed five Solar ABS deals to date, totaling USD1.2bn.

There are also opportunities for investing in low-carbon energy projects in developing countries. SunFunder started operating as a financial intermediary in 2012, with the aim of providing financing for solar assets located in emerging markets. ${ }^{52}$ The company connects investors to vetted solar businesses working on the ground in Africa, Latin America, Asia and the Caribbean.

Crowdfunding trends have started to influence green and ethical banks' business models. In early 2018, Triodos Bank launched its own crowdfunding platform enabling UK residents to directly fund renewable energy projects. ${ }^{53}$

Low-carbon funding platforms are not exclusively limited to renewable energy. Abundance Investment is a UK-based online investment platform that enables investors to fund companies and projects within the energy, energy efficiency and housing sectors at different stages of development. ${ }^{54}$ Investments can be made both directly, in the form of tradable debentures, as well as via an Individual Savings Account (ISA), which offers tax advantages.

\section{Green banking services and investment products}

A number of banks have started offering or expanding their green and sustainable banking services to address demand from customers who want their money to be invested or lent only to companies meeting certain screening criteria. Banking products include green deposit accounts, savings accounts, ISAs, funds, lending and mortgages.

Dutch Triodos Bank was a pioneer in the ethical banking sector, having started to offer sustainable financial products in 1980. As of the end of 2017, the bank had EUR15bn AUM and directed 52.3\% of loans and investments exclusively to environmental projects. ${ }^{55,56}$

Further, Triodos Investment Management offers fund investment opportunities for both institutional and individual investors in six European countries and the USA. investment themes include "energy and climate", "sustainable food and agriculture" and "sustainable real estate". ${ }^{57}$

German direct bank UmweltBank AG is an example of a bank fully specialised in funding green projects related to renewable energy, green buildings and organic farming. The bank has set out a list of eligibility and exclusionary criteria as part of its screening process. ${ }^{58}$

In India, YES BANK set up its first green deposit in May 2018. Proceeds raised through the accounts will be earmarked to fund SDG-aligned sectors. ${ }^{59}$

In mid-2018, 37 of Europe's leading banks, including BNP Paribas (France), ING Bank (Netherlands) and Société Générale (France), signed up to a pilot scheme led by the World Green Banking Council, which aims to incentivise improvements in the energy efficiency of buildings by offering lower mortgage rates to owneroccupiers. ${ }^{60}$ ABN Amro (Netherlands) was the first bank to raise green bond funding in 2015 to finance green residential mortgages, which are secured on energy-efficient homes and/or will be used for rooftop solar installations on existing homes. 


\section{The role of government and the public sector: lead from the front lines, promote and sponsor growth}

Development banks, government-backed entities, local governments and sovereigns represent $26.5 \%$ of the global green bond market. Their deals finance national climate agendas and support market development. The bonds are typically earmarked for investment in a wide array of sectors, but particularly transport, water infrastructure and public buildings.

\section{Sovereign boom builds on local government success}

Sovereign bonds from Belgium, France and Poland have boosted volumes recently (for a full list see page 5) and the line-up for 2019 issuance is already strong (see next page).

Local government green bond issuance paved the way. French and Swedish local governments were among the first green bond issuers when they entered the market in 2012/13. Local governments - cities, municipalities, regions, states and provinces - are generally earlystage green bond adopters in their respective domestic markets and typically continue to issue on a regular basis. This demonstrates their commitment and awareness, and helps to achieve their country's climate and energy efficiency goals.

Over the last year or so, sustainability bonds have become increasingly popular among local governments as they seek to integrate social development projects with climate finance. We view green bonds as a bridge to achieving sustainable development goals. They enable large-scale financing of sustainable and climate-resilient public infrastructure as well as the funding of climate adaptation measures. ${ }^{61,62}$ However, we continue to apply the term "green" to bonds that finance almost exclusively climate solutions (see page 23 for a discussion on the wider labelled market).

A rising preference for sustainability bonds, particularly in some big markets such as France, is one of the reasons why 2018 green bond issuance from local governments back has retreated back to 2016 levels. The other contributing factor is lower issuance volume from US Munis. For instance, the top two US states for green bond issuance in 2017, New York and California, recorded the greatest decrease in annual volume in 2018 (NY: USD4.6bn to USD835m, CA: USD4.3bn to USD1.5bn). Tax changes in the US and rising interest rates have dampened US Muni and other bond issuance.

There is room to further democratise the local government segment of the green bond market on a global scale, as currently only 14 nations have seen their domestic local authorities issue green bonds. Existing bond issuers are in a good position to finance or refinance green assets/projects in the green bond market.

\section{Public sector companies can help with scale}

Public sector issuance commenced in 2010 with state-owned local government funding agency KBN (Norway). Since then, there has been a steady stream of issuance from state and local government companies, particularly from the Nordics and France, where the national climate policy is very supportive. In the USA, state agencies and other entities such as transport authorities, water utilities and universities (US Munis) have adopted green bond issuance as part of their strategy, notwithstanding a less supportive federal policy.

In our various public sector issuer scoping studies, the aim was to identify existing bond issuers among local governments (cities, municipalities, states), municipally owned companies (MOCs), stateowned enterprises (SOEs) or funds, as well as Local Government Funding Agencies (LGFAs) from a specific region/country. We have identified such potential issuers in a number of reports (see box).
Public sector growth in the green bond market has shifted from the initial development banks' push

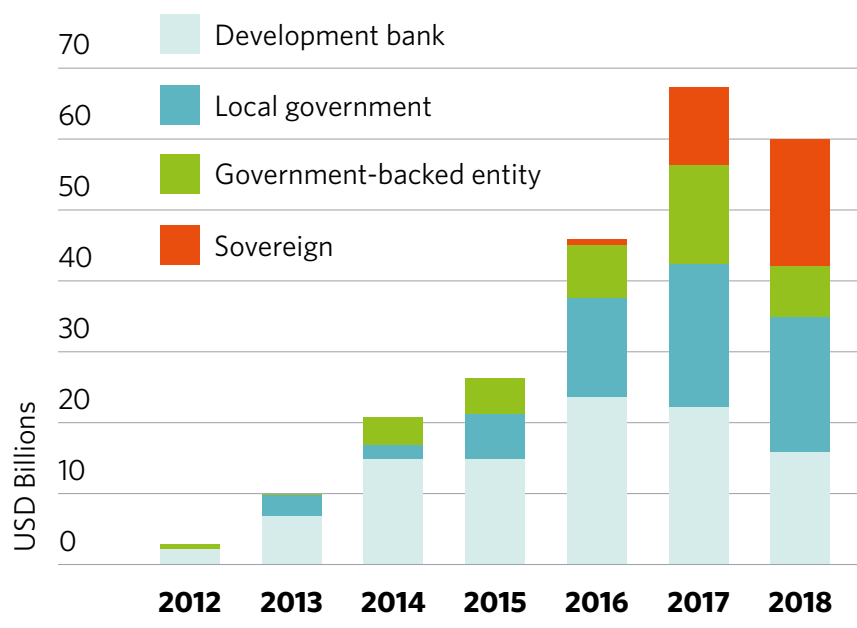

Canadian and Australian local government issuers upped their game in 2018, as US Munis retreated

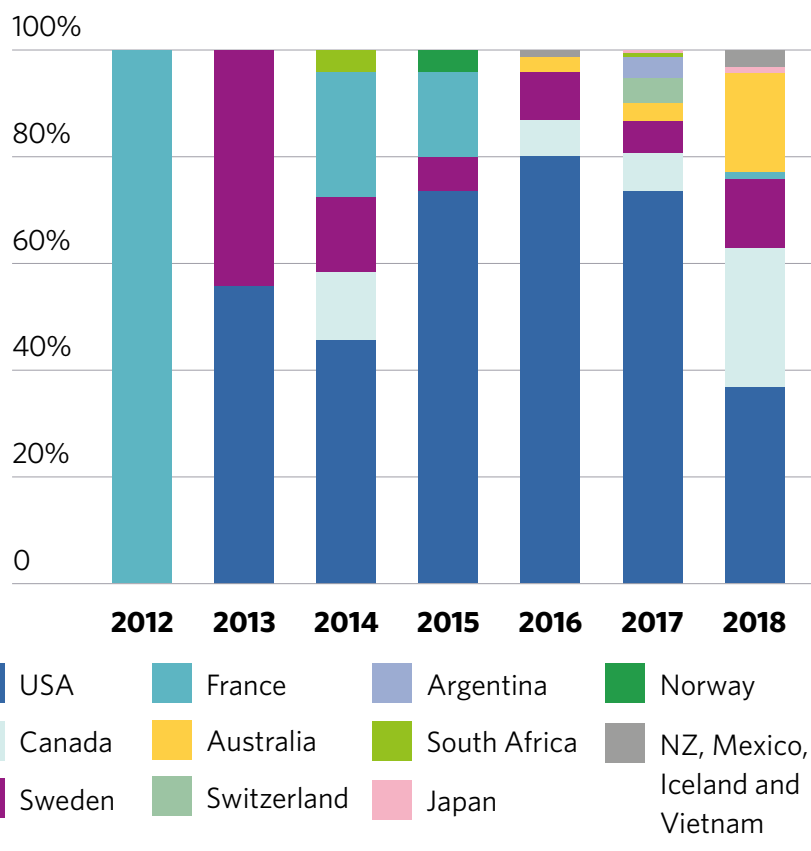

Potential public sector issuers - report links

- Japan (CBI, March 2019): We highlighted four of the largest government agencies as potential issuers. ${ }^{63}$ Japan Housing Finance Agency issued its first green bond in January 2019.

- ASEAN region (CBI, January 2019): We identified 47 existing public sector issuers with USD125bn of bonds outstanding, of which $22 \%$ issued internationally. ${ }^{64}$

- France (CBI, April 2018): 25 local government vanilla bond issuers were identified. ${ }^{66}$ Since the publication of this briefing, Region Pays de la Loire joined the market.

- Nordic and Baltic markets (CBI, February 2018) are replete with growth opportunities on the public sector side from LGFAs, through housing associations and district heating to import-export agencies and development funds. 67,68 


\section{Governments shape green bond policy}

This section covers the main policy highlights from 2018. More details can be found in the Green Bond Policy Roundup 2018.

\section{Sovereign green bond growth}

2018 has witnessed additional green sovereign issuance. Landmark issuance includes the world's first blue bond issued by the Republic of Seychelles and the first sovereign green sukuk from Indonesia. Poland became the first EM sovereign to issue a second sovereign green bond. Ireland, Lithuania and Belgium also entered the market. France tapped its Green OAT twice, bringing the total bond size to EUR14.8bn. Finally, the Netherlands, Spain, Kenya, Egypt, Hong Kong and Vietnam are all in the pipeline for sovereign green bond issuance in 2019. 9,10,11,12,69,70

For more on sovereign green bonds, please see the CBI Sovereign Green Bonds Briefing. ${ }^{71}$

\section{National guidelines for green bonds}

The second half of 2018 saw green bond guidelines published in Egypt and the Philippines.

In Egypt, the Financial Regulatory Authority (FRA) approved a legal framework for issuing green bonds in July 2018, with the aim of providing financial tools to fund eco-friendly projects in the fields of new and renewable energy, construction and transport. The guidelines were developed with the support of IFC, a member of the World Bank Group, and are based on the international guidance provided by the Green Bond Principles. ${ }^{72}$

In August, the Philippines Securities and Exchange Commission approved the Guidelines on the Issuance of Green Bonds under the ASEAN Green Bond Standards, effectively adopting the procedures for issuance set out in the ASEAN Green Bond Guidelines. The Guidelines are based on the international Green Bond Principles with a clear exclusion of fossil fuel power generation projects. ${ }^{73}$

\section{EU TEG Process}

Following the final report of the High Level Expert Group (HLEG), in 2018, the European Commission launched a Technical Expert Group (TEG) on sustainable finance. The TEG is composed of 35 experts from industry and civil society. Sean Kidney, CEO of Climate Bonds, is a TEG member.

The TEG is tasked with different activities, including addressing Action 1 under the Action Plan for Europe, which calls for the establishment of an EU classification system for sustainable activities. The EU Taxonomy for Sustainable Finance is currently being discussed by the European Parliament and Member States.

In the first phase of work, the TEG Taxonomy subgroup identified priority sectors to develop a range of activities, especially where guidance and criteria are already available and used by markets. Forestry, buildings, manufacturing, energy and transportation were all sectors of focus. A consultation paper was published in December. ${ }^{74}$

In its second round, the TEG identified further sectors. Workshops and meetings will be held with external experts to define an eligible list of activities, which is to be delivered in June 2019.

\section{Central banks' action}

Central banks' action towards management of climate and environmentrelated risks has increased in 2018, witnessed by the first meeting of the Network for Greening the Financial System (NGFS). The group, which comprises 24 central banks and supervisors and five international organisations, has released its first progress report. Key messages include the need for new analytical and supervisory approaches to assess climate-related risks, including scenario analysis and stress tests. ${ }^{75}$

Some members are already taking action with increased assessment of prudential risks. Central banks have started integrating climate-related factors in their investment strategies and introducing incentives for supervised banks to increase green lending and to issue green bonds.

\section{Availability of national and regional green bond guidance}

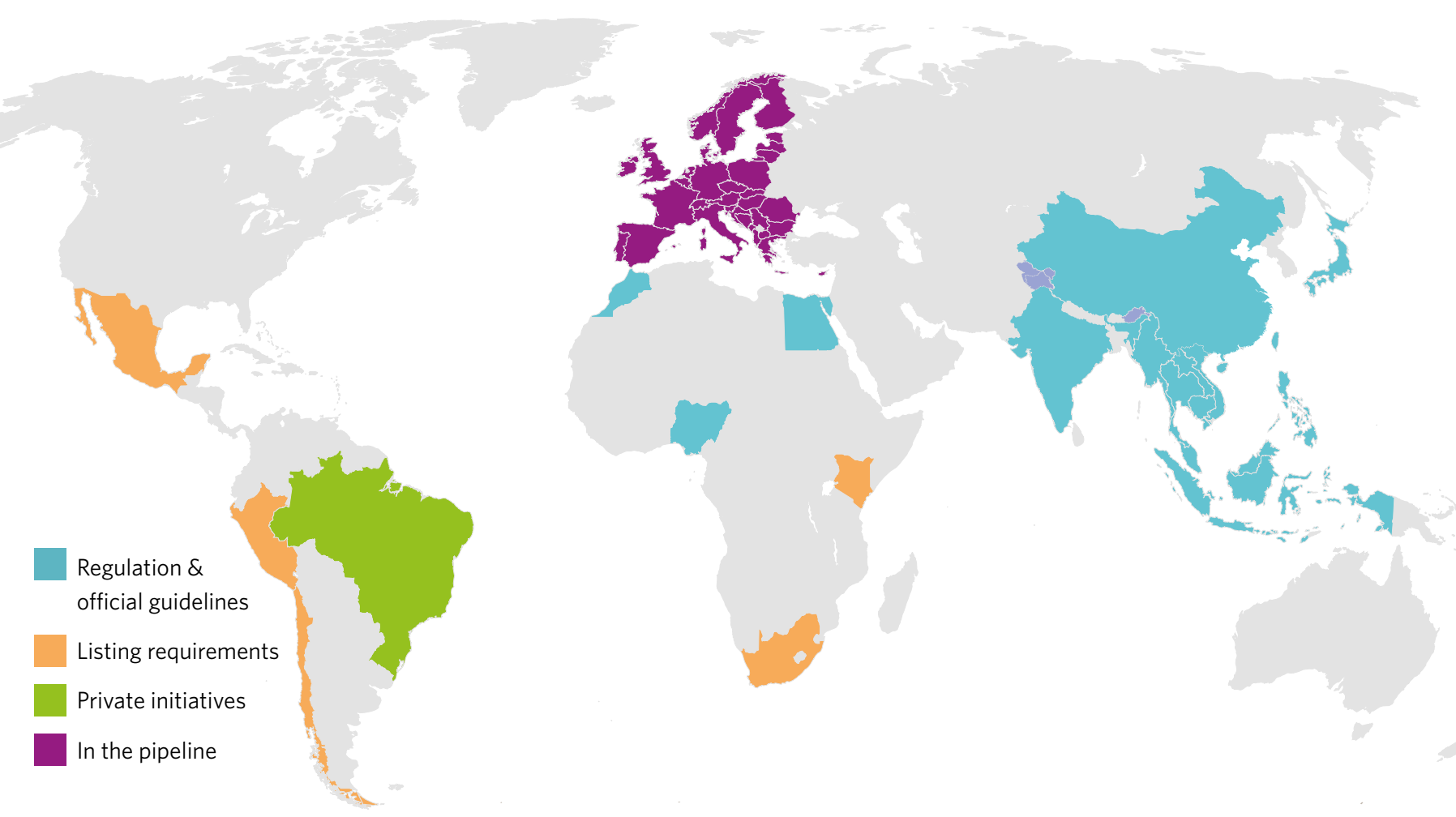




\section{The wider labelled universe: sustainability bonds, social bonds, SDG bonds, blue bonds ...}

The labelled bond market has expanded beyond green bonds. Sustainability and social bonds have been around for a few years now, but they really came into their own in 2018, with SDG bonds also emerging as issuers and investors started adopting policies and strategies linked to the UN's 17 Sustainable Development Goals. ${ }^{76}$

\section{Green bonds and the Sustainable Development Goals}

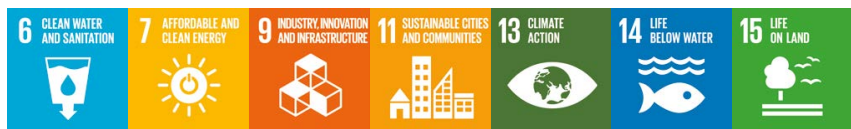

Climate Bonds supports the Sustainable Development Goals (SDGs) overall, and we see many links between green bond finance and specific SDGs, in particular SDGs 6, 7, 9, 11, 13, 14 and $15 .{ }^{61}$ Notwithstanding this, $\mathrm{CBI}$ remains focused on green bonds, which are specifically linked to climate-change mitigation and adaptation $\&$ resilience. Consequently, the proportion of proceeds allocated to social projects which are not also green needs to be no more than $5 \%$ for inclusion in the $\mathrm{CBI}$ green bond database.

\section{Sustainability and SDG bonds}

Sustainability and SDG bonds may allocate proceeds to green assets only or a mix of green assets and social projects. 2018 sustainability bond issuance totalled USD21bn, according to Climate Bonds data. This represents $114 \%$ growth compared to 2017. Adding these bonds to CBI's green bond tally of USD167.6bn results in a total of USD188.6bn, or a 10\% year-on-year increase.

Sustainability bond frameworks often provide separate green and social eligibility categories. If specific allocations per category are not provided, CBI assumes an equal split. For instance, Korea Railroad Corporation issued a EUR110m (USD127m) senior bond in October 2018. The issuer's Green, Social and Sustainability Bond Framework includes five green eligibility categories (transport, energy, energy efficiency, waste and adaptation) and three social categories (access to basic infrastructure, employment generation and socioeconomic advancement and empowerment). ${ }^{79}$ Applying an equal split among categories results in $38 \%$ of funding allocated to social projects, and the rest for climate-aligned projects.

Région Occitanie (France) also came to market in late 2018 with a EUR200m (USD235m) senior unsecured bond. According to the Green and Social Bond Framework, funding will be allocated to projects in ecological and energy transition, natural resources protection, social action, and education and culture. ${ }^{80}$ This points to a $50 \%$ split of funding between social and green projects.

\section{SDG Bond Frameworks}

2018 has witnessed the emergence of SDG frameworks, which distinguish between green and social eligibility criteria and allow the issuer to classify a bond as "green", "sustainability" or "social" depending on the use of proceeds.

These frameworks allow the issuer to keep a clear distinction between bonds that finance environmental projects and social projects. This makes it easier for investors with a dedicated mandate to identify bonds that comply with their investment criteria. BBVA became a frontrunner in this field, with a EUR1bn green bond issued in May under its newly developed SDG Bond Framework. 77,78
Label diversification is increasing beyond green bonds

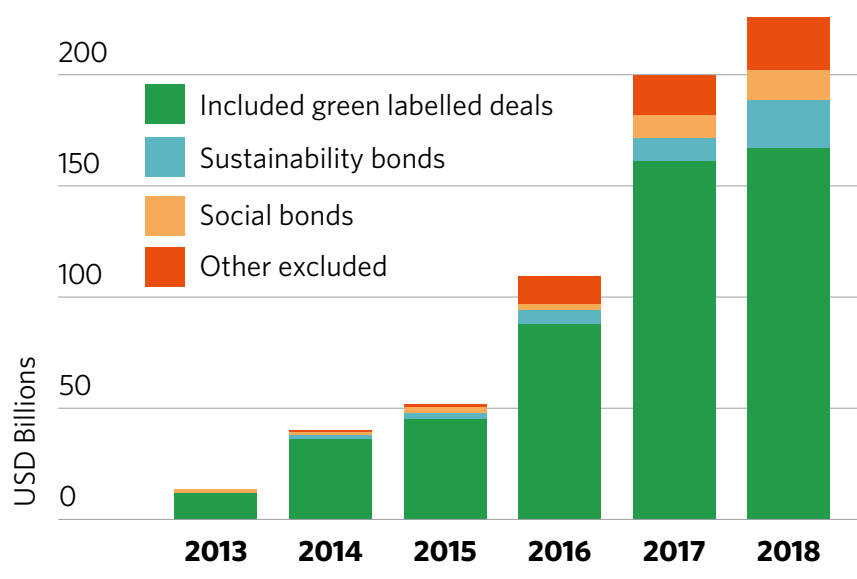

In cases such as these, Climate Bonds would not include the bonds in the $\mathrm{CBI}$ green bond database as the social component appears to exceed our $5 \%$ limit. While it is obvious that some of the funding will go towards the types of assets and projects that are financed by green bonds, the lack of detail on allocations precludes us from estimating the volume of proceeds going to green assets/projects.

We have also started seeing ESG-linked loans. For instance, in early 2018, Dutch bank ING provided its first Asian sustainability performance-linked loan to Wilmar International, a palm oil producer from Singapore. ${ }^{81}$ Sustainalytics will track annually improvements in targets based on ESG metrics. If the performance milestones are met, the interest rate for part of the loan will be reduced for the following year. While the performance-linkage is a positive feature, it is unclear if the loan will finance assets or projects with a clear climate benefit and what part of the loan will be used to fund that. Consequently, the deal is not included in the $\mathrm{CBI}$ green bond database, as there is insufficient information to determine alignment to the Climate Bonds Taxonomy.

\section{Social bonds}

Social bond issuance also increased in 2018, albeit less dramatically than sustainability bonds, with USD14.2bn worth of deals coming to market in 2018 - a 37\% year-on-year growth. Adding social bonds to green and sustainability volumes would yield an annual total of USD202.5bn, or $11 \%$ above 2017 volumes.

Notably, CBI treats bonds which finance social projects with a climate angle - e.g. social housing upgrades to improve energy efficiency by $25 \%$ or more - as green bonds, and analysed accordingly. However, bonds which finance social goals / projects without a clear climate angle, would not be included in the CBI green bond database.

NWB Bank is an example of a repeat issuer of both green and social bonds. The Dutch financing institution has issued seven social bonds between 2017 and 2018, for a total of EUR5.2bn (USD6bn). As stated in the Social Bond Framework, proceeds will be fully allocated to affordable housing projects in the Netherlands. ${ }^{82}$

Spanish state-owned bank Instituto de Crédito Oficial debuted in the social bond market in November 2018 with a EUR500m (USD566m) senior unsecured deal. According to the Social Bond Framework, eligible projects include loans to fund SMEs located in an underperforming region of Spain that are not involved in industries considered to have a potential negative social or environmental impact, including alcohol, tobacco, gambling and coal mining. ${ }^{83}$ 
2018 issuance including sustainability and social bonds

250

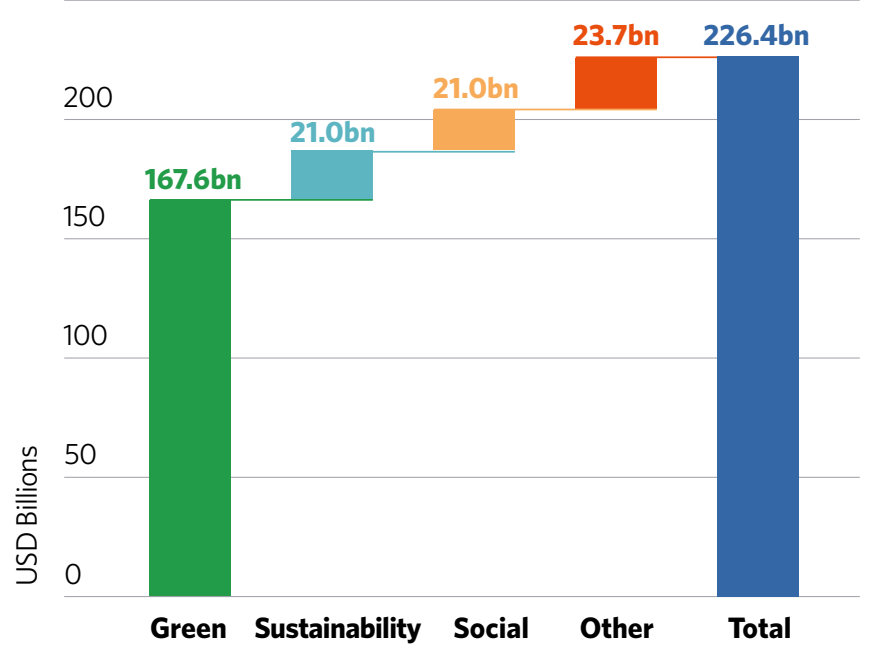

\section{Other labelled bonds}

Some labelled green bonds are excluded from the CBI green bond database, because $\mathrm{CBI}$ screens the use of proceeds for alignment to the Climate Bonds Taxonomy and limits non-aligned allocations to 5\%. ${ }^{7}$ Excluded bonds of USD58.9bn in 2018 comprised sustainability and social bonds, as well as such excluded green bonds.

Green bonds allocating a significant share of proceeds to working capital represent $20 \%$ of excluded deals in 2018 . The majority of bonds under this category are from Chinese issuers, as working capital is an eligible category under the guidelines released by the National Development and Reform Commission (NDRC).

Bonds which are not aligned account for $18 \%$ of 2018 's excluded volumes. One of the main reasons for exclusion under this category is the allocation of proceeds to fossil fuel-related projects, including improvements in energy efficiency of fossil fuel-based technologies. Chinese issuers represent around half of the exclusion category's share due to the financing of coal assets, which is allowed under the People's Bank of China green bond catalogue.

Factoring in all labelled issuance brings the 2018 total of labelled bonds to USD226.4bn, or 13\% up over the 2017 volume of USD199.3bn.

\section{Are blue bonds green? ... and other labels}

There are many more labels in the market: climate-awareness bonds, solar bonds, wind bonds, PACE bonds, etc. This can be confusing but needn't be. CBI uses the labelling for initial identification, but looks through to the assets and projects the debt finances to determine, if it is climate-aligned. ${ }^{4}$

Blue bonds, which fund marine conservation and sustainable fisheries are green, since they finance sustainable land use and marine resources, and land and marine conservation.

Forest bonds could also be green when they fund sustainable forestry, forest conservation and/or afforestation. In 2016, the IFC placed a USD152m "forests bond" to protect tropical forests in Costa Rica and avoid deforestation. It offered investors coupons in either cash or carbon credits. ${ }^{84}$

Blue Forest Conservation has set up a US platform to combine public and private funding for forest protection and restoration, with the aim of reducing the risk of wild fires, protecting water resources, avoiding carbon emissions and creating rural jobs. The pilot forest resilience bond was launched in 2018 in Tahoe National Forest. ${ }^{85}$
Sustainable land use and natural resource conservation is one of the pathways to build climate resilience. More broadly, adaptation and resilience $(A \& R)$ presents new opportunities, in both developed and developing countries. ${ }^{62}$ Blue bonds and forest bonds are likely a harbinger of more labels to come for A\&R financing. In anticipation of increased interest in accessing the bond market to fund this, $C B I$ convened an Adaptation and Resilience Expert Group to discuss and develop the A\&R Principles, which will provide high-level guidance for determining when projects and assets are compatible with a climate-resilient economy. ${ }^{86}$

Another new label is climate action bonds, a term recently used by Italian gas utility Snam to highlight that their deal is funding the transition to a low-carbon economy but may not be seen as a green bond by some. Eligible categories include renewable energy, LED lighting and conservation areas, but also emission reduction projects for existing gas grid infrastructure. ${ }^{87}$

Fossil fuel power generation and infrastructure does not meet CBI's green bond screening criteria, so the bond is not included in the $\mathrm{CBI}$ green bond database. Notwithstanding this, the label and/or variations, which reference transition could be useful for companies that are financing their brown-to-green transformation.

Notably, however, many companies in the energy sector, such as EDF, Enel, Engie and Iberdrola, have used green bonds to finance investments in renewable energy, as well as in low-carbon buildings, low-carbon transport, sustainable water and waste management. In fact, the green bond label is particularly valuable to companies in transition, as it showcases their aspirations and commitment to financing climate-change mitigation, adaptation and resilience.

\section{Outlook for 2019 labelled issuance and beyond}

2018 has been a year of consolidation for the green bond market with good progress in the development of taxonomies and harmonisation efforts. As a result, we would hope to see greater alignment of future deals to the Climate Bonds Taxonomy (see Appendix 2), ${ }_{1}^{4}$ which should lead to fewer exclusions in CBI's screening process. ${ }^{7}$

More broadly, clearer definitions of what is sustainable/green and improved disclosure on the projects being financed and their environmental impact can help investors assess the market and individual bonds. The rising number of dedicated green bond funds and the increased focus on ESG across the investment community is beneficial to scaling up the green bond market.

CBI's target for green bond issuance in 2019 is USD250bn. It is an ambitious target, because it needs to be to slow down the impacts of climate change. Issuers, investors and governments are increasingly aware of the need to scale up climate finance and we hope we will see increased issuance - more issuers, more repeat issuance and a further rise in green bond issuance from banks, acting as aggregators for the loan market.

Canada, for instance, has started 2019 well with repeat issuance from pension fund CPPIB, one new issuer and two deals from repeat issuers. ASEAN, too, with one new Philippine issuer of Certified Climate Bonds becoming a repeat issuer in short order and a second sovereign green sukuk from Indonesia. France and Poland have both come back to market to finance their national transitions. Japan Housing Finance Agency entered the market with a bond financing new energy-efficient houses. And the list goes on...

We also expect the wider labelled bond market - sustainability bonds, SDG bonds, ESG-linked debt and social bonds - to continue growing, and estimate that the overall labelled bond market would reach USD300bn in 2019. 


\section{Climate Bonds 2019 green investment picture}

\begin{abstract}
The October 2018 release of the IPCC SR15 report has exploded any faint illusions that the world still has the comfort of decades to take decisive action on climate ${ }^{89}$ There is a plethora of reports estimating the levels of finance in green infrastructure needed through the 2020s to influence outcomes to 2050-2060. ${ }^{90,91,92}$
\end{abstract}

Christiana Figueres and five other climate leaders called for USD1tn in green finance by 2020 as part of Mission2020's six climate milestones in early 2017. ${ }^{93}$ Two years later, taking into account private climate-based investment, it seems the main actors in the global financial system are yet to demonstrate the level of capital 'adaptation' Ms Figueres defined as a performance measure.

The OECD estimates that USD6.9tn a year is required up to 2030 to meet climate and development objectives in its report Financing Climate Futures: Rethinking Infrastructure. It further notes that current energy, transport, building and water infrastructure make up more than $60 \%$ of global greenhouse gas emissions, and stresses that an unprecedented transformation of existing infrastructure systems is needed to achieve the world's climate and development objectives. ${ }^{94}$

In 2018, green bond issuance was USD167.6bn. While green bonds are not the be-all, end-all of climate finance, issuance needs to be scaled up to help fund that transformation and the transition from a largely "brown" economy to a "green" one.

\section{8 has been a year of progress on the path to defining and} harmonising the definition of green. The EU TEG on Sustainable Finance has continued work on developing a EU taxonomy and stepped up efforts to harmonise approaches globally. The Expert Panel on Green Finance in Canada is working towards its final report and, in Australia, investor and ESG groups have sidestepped political inertia and are forming a Sustainable Finance taskforce. The lowprofile central bank-led Network for Greening the Financial System is due to publish its first comprehensive report in April 2019.

China continued its steps towards greening its financial system. Mexico, Morocco and Nigeria introduced green bond guidelines, as did the Lima and Santiago stock exchanges. The UK is acting on its Green Finance Taskforce recommendations to enhance London's burgeoning role as a green finance hub.

ICMA updated the Green Bond Principles, incorporating SDG factors, and published the Social Bond Principles and Sustainability Bond Principles. ${ }^{2}$ The Loan Market Association's Green Loan Principles, released in March 2018, ${ }^{3}$ can have an even greater impact on how banks finance infrastructure, property and industry. A year on, the IFC has announced that it will begin applying the GLPs to spur the growth of the USD33bn green-loan market. ${ }^{88}$

CBI updated its Taxonomy in 2018 and will shortly release the Standard Version 3.0, a complete overhaul of CBI's umbrella guidance for Certification, after a year-long development process to expand the science-based Standard and sector Criteria.

In response to investor demand for disclosure on the impact of green bonds, ICMA continued enhancing its suite of impact reporting guidelines with suggested metrics and templates for Waste Management and Resource-Efficiency Projects and Clean Transportation Projects in 2018.95

CBI's research into post-issuance reporting found that two thirds of issuance by amount had use-of-proceeds and impact reporting. Notably, we found that a third of bonds, for which there was no specific upfront commitment, did, in fact, report. This suggests issuers understand the need for transparency and disclosure.

\section{Against the ticking clock that SR15 loudly amplified, pressure} comes from all quarters to increase climate and green investment The predictions of annual issuance for 2019 range from USD140bn to USD300 bn. ${ }^{96}$ However, what is really needed is a trillion a year. That continues to be the big benchmark that banks, insurers and corporates must deliver. By end 2020 the public scrutiny on those who are not investing in green and contributing to the transition to a low-carbon economy will likely be sharper.

In the interim, investors are pushing harder on the world's largest emitters. The Climate Action 100+ initiative, one of the projects that form the 'Investor Agenda', has established a straight line of corporate governance engagement between a USD32tn coalition of institutional investors and the 160 largest global emitters. ${ }^{97}$

Speeding the brown-to-green transition is one of the end points of the engagement. This must mean attention moving from risk assessments and statements of intent to actual investment from large emitters. ${ }^{98}$ An investor letter to EU power industry generators, grid operators and distributors reflects this coming focus, calling for capital expenditure plans 'compatible with the Paris Agreement' and, in time, with a zero-carbon economy. ${ }^{99}$ Metals, mining, the chemical and cement industries will also face similar calls in the future.

Brown-to-green transition in practice means large companies straddling both brown and green assets, and the sooner investor pressure results in greener capex, the better. Inevitably, the first deals from high-carbon emitters will be greeted with the ever-present cries of 'greenwashing'. Civil society is right to be sceptical, but such a development could trigger a positive debate in 2019.

Some of the world's biggest banks - ICBC, Bank of China and Industrial Bank - have issued benchmark-sized Certified Climate Bonds. Top 100 banks in Australia, Canada and Europe have also issued green: 11 of the Top 15 green bond underwriters are green bonds issuers. The creation of the Sustainable Banking Network underpins efforts to share knowledge and maximise impact. ${ }^{100}$

More banks need to lead on green bonds, green loans, green mortgages and other retail and corporate banking and investment products in 2019 and beyond. Those that do not, will, in time, face institutional investors and civil society framing the green investment question as fundamental to their licence to operate.

A banking sector that collectively can still hold trillions in brown investments around the world but cannot make its vital contribution reaching the first trillion of green should expect no less.

Nation states as sovereign issuers of green bonds also have a role. Kenya, the Netherlands and Egypt have foreshadowed 2019 green issuance. Yet gaps remain amongst G2O, OECD and EMEA nations. Treasuries and Finance Ministries can deploy green bonds to finance NDCs under the Paris Agreement, but, more importantly, sovereign issuance raises the country's green profile for investors, and has the power to mobilise private capital and spur additional issuance.

This year will see a strengthening of grassroots calls for more nations to act. We are not on track to limit temperature growth under $2^{\circ} \mathrm{C}$; rather, we are on track to reach $3^{\circ} \mathrm{C}$ or more.

The impacts already in the planetary system are worse than we thought. The trillions needed through the next decade to support low carbon growth paths in China, India, Africa and Latin America are not yet in sight.

What is really at stake in 2019 is not so much a calendar issue, it is whether we cruise or accelerate into the 2020s. 


\section{Appendix 1 External review types}

\begin{tabular}{|c|c|c|}
\hline Pre-issuance review & Scope & Providers \\
\hline Assurance & $\begin{array}{l}\text { Positive or negative assurance on compliance with the } \\
\text { Green Bond Principles (GBP) or the Green Loan Principles } \\
\text { (GLP) }\end{array}$ & EY, Deloitte, KPMG, etc \\
\hline Second Party & $\begin{array}{l}\text { Confirm compliance with GBP / GLP. Provide assessment } \\
\text { of issuer's green bond framework, analysing the } \\
\text { "greenness" of eligible assets }\end{array}$ & $\begin{array}{l}\text { CICERO, Sustainalytics, Vigeo-Eiris, } \\
\text { DNV GL, SynTao Green Finance, } \\
\text { CECEP Consulting, etc }\end{array}$ \\
\hline Green bond rating & $\begin{array}{l}\text { Rating agencies assess the bond's alignment with the } \\
\text { Green Bond Principles and the integrity of its green } \\
\text { credentials }\end{array}$ & $\begin{array}{l}\text { Moody's, S\&P, CCX (China), } \\
\text { ChinaBond Rating, R\&I and JCR } \\
\text { (Japan), RAM (Malaysia) }\end{array}$ \\
\hline Pre-issuance verification & $\begin{array}{l}\text { Third party verification confirms that the use of } \\
\text { proceeds adheres to the Climate Bonds Standard and } \\
\text { sector specific criteria }\end{array}$ & $\begin{array}{l}\text { Approved verifiers under the Climate } \\
\text { Bonds Standard scheme }\end{array}$ \\
\hline Post-issuance review & Scope & Providers \\
\hline Assurance or SPO & Assurance of allocation of proceeds to eligible green projects & $\begin{array}{l}\text { Audit firms, ESG service providers, } \\
\text { scientific experts }\end{array}$ \\
\hline Impact report & $\begin{array}{l}\text { Reporting that seeks to quantify the climate or } \\
\text { environmental impact of a project/asset numerically }\end{array}$ & As above \\
\hline Post-issuance verification & $\begin{array}{l}\text { Assurance against the Climate Bonds Standard, including } \\
\text { allocation of proceeds to eligible green projects and types } \\
\text { of green projects }\end{array}$ & Approved verifiers \\
\hline
\end{tabular}

\section{Appnedix 2 Climate Bonds Taxonomy}

\section{Climate Bonds Taxonomy}

The Climate Bonds Taxonomy identifies the assets and projects needed to deliver a low carbon economy and gives GHG emissions screening criteria consistent with the 2-degree global warming target set by the COP 21 Paris Agreement. More information is available at https://standard.climatebonds.net/taxonomy.

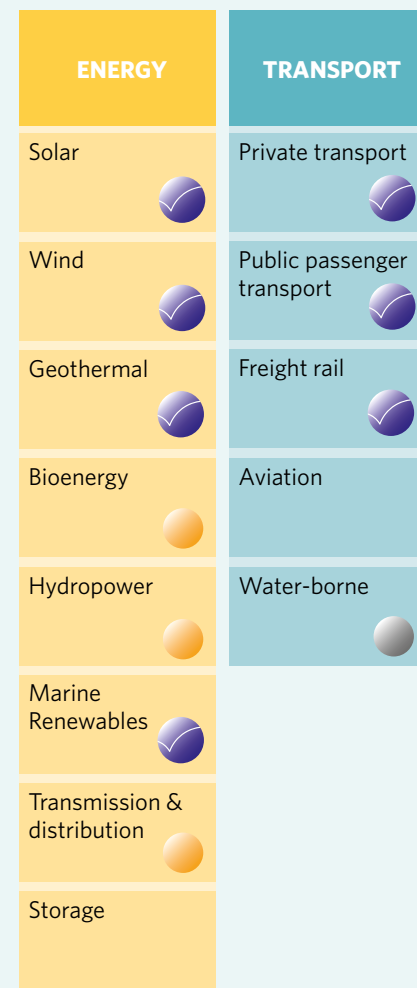

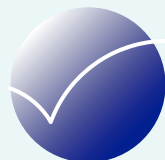

Climate Bond Certified

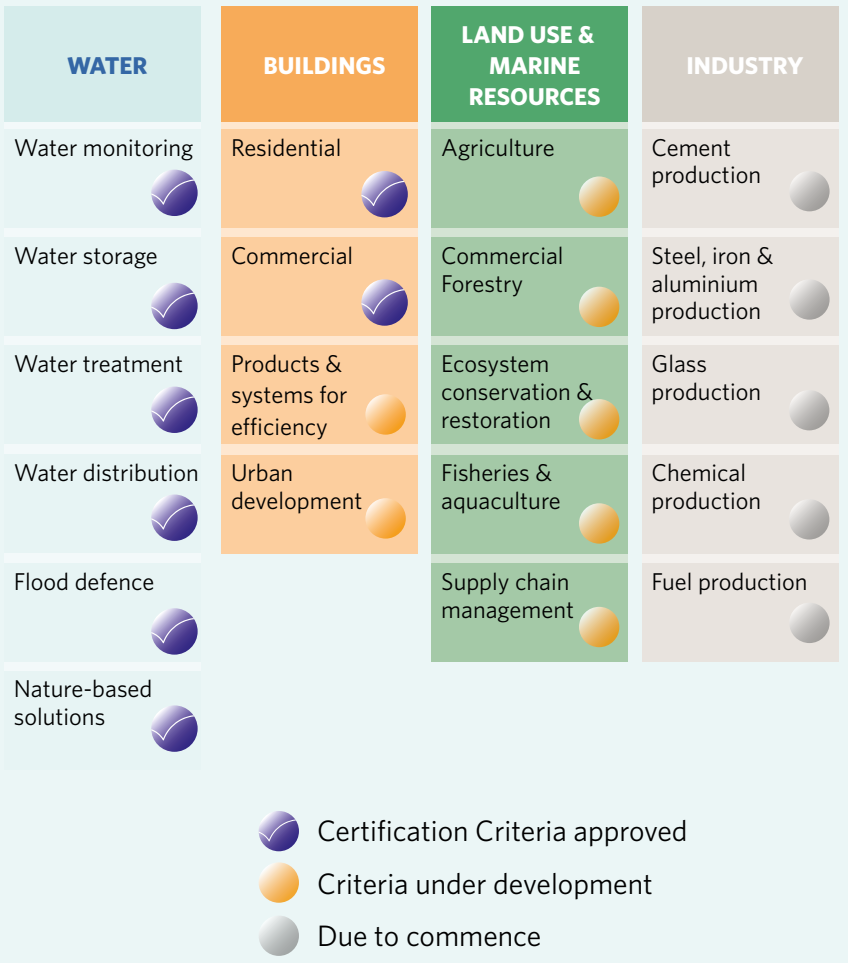

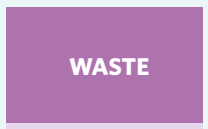
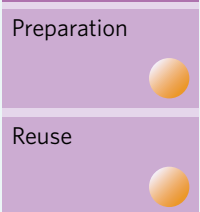

Recycling

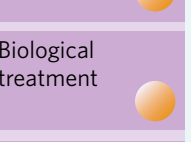

Waste to energy

Landfill

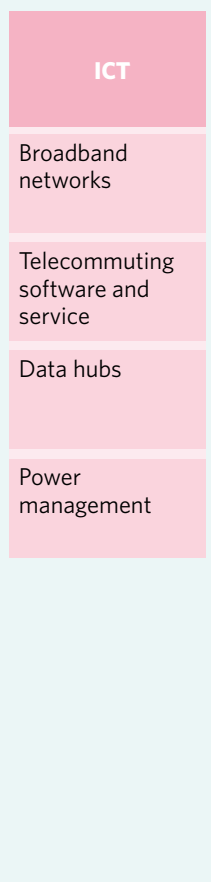


1. https://www.climatebonds.net/resources/reports/2018-greenbond-market-highlights

2. https://www.icmagroup.org/green-social-and-sustainabilitybonds/green-bond-principles-gbp/

3. Green Loan Principles, LMA, Mar 2018: https://www.Ima. eu.com/news-publications/press-releases?id=146

4. https://www.climatebonds.net/standards/taxonomy, Sep 2018.

For a summary overview see Appendix 2 opposite.

5. https://www.climatebonds.net/standard/sector-criteria, Nov 2018

6. https://www.climatebonds.net/standards/about

7. CBI Green Bond Database Methodology at https://www.

climatebonds.net/market: https://bit.ly/2tQ5brJ

8. See Bonds and Climate Change: The State of the Market 2018,

CBI, Sep 2018: https://www.climatebonds.net/resources/reports/

bonds-and-climate-change-state-market-2018

9. https://www.investmenteurope.net/news/4000244/spain

issue-sovereign-green-bond

10. https://www.pv-magazine.com/2018/11/02/netherlands-

government-to-issue-green-bonds-in-2019/

11. https://www.financeasia.com/News/449309,hong-kong-to-

issue-first-sovereign-green-bonds-this-year.aspx

12. https://enterprise.press/stories/2018/11/07/egypt-to-issue-

green-bonds-next-fiscal-year/

13. https://www.climatebonds.net/resources/reports/asean-green-

financial-instruments-guide

14. https://presse.credit-agricole.com/actualites/finance-climat

-le-credit-agricole-complete-son-leadership-mondial-en-

obligations-vertes-avec-une-emission-inaugurale-de-1-milliard-

deuros-pour-financer-ses-engagements-en-faveur-de-la-transition-

energetique-761e-9ed05.htm

15. http://www.elexica.com/en/legal-topics/capital-

markets/020818-new-senior-preferred-class-of-bank-debt-

introduced-in-germany

16. https://www.prometeia.it/en/atlante/senior-non-preferredbond-what-are-they

17. https://www.bbva.com/en/bbva-launches-first-green-bond/

18. http://www.fanniemae.com/portal/jsp/mbs/mbsmultifamily/

gems_archive.htm

19. https://www.climatebonds.net/ing-bank-n

20. https://www.climatebonds.net/societe-du-grand-paris

21. https://www.climatebonds.net/certification/dnb-boligkreditt

22. Post-issuance reporting in the green bond market, Mar 2019:

https://www.climatebonds.net/resources/reports/post-issuance-

reporting-green-bond-market

23. https://www.climatebonds.net/resources/reports/post-

issuance-reporting-green-bond-market-trends-best-practice-

june-2017

24. https://www.msci.com/market-classification

25. https://www.climatebonds.net/programmatic-certification

26. Heat map - 11 sectors with $\$ 2.2$ tn debt have elevated

environmental risk exposure, Moody's, Sep 2018

27. https://www.climatebonds.net/resources/reports/china-green-

bond-market-2018

28. https://www.climatebonds.net/resources/reports/india-

country-briefing-july-2018

29. https://www.climatebonds.net/resources/reports/asean-green-

finance-state-market-2018

30. ASEAN Green Bond Standards, ACMF, Nov 2017

31. https://www.climatebonds.net/resources/reports/korea-

climate-bond-market-overview-and-opportunities

32. Small island credit profiles resilient to near-term climate shocks,

but climate trends pose longer-term risk, Moody's, Dec 2017

33. Can green bonds finance Brazil's agriculture?, CBI, Nov 2018

https://www.climatebonds.net/resources/reports/can-green-

bonds-finance-brazil\%E2\%80\%99s-agriculture
34. https://newsroom.barclays.com/r/3559/barclays_launches_ pioneering range_of green_corporate

35. https://www.westpac.com.au/about-westpac/media/mediareleases/2018/26-november2/

36. https://www.amundi.lu/professional/product/view/

LU1688575510

37. https://www.lyxoretf.co.uk/en/instit/products/fixed-income-

etf/lyxor-green-bond-dr-ucits-etf-acc/lu1563454310/eur

38. https://www.vaneck.com/row/

39. https://www.ishares.com/us/products/305296/

40. https://www.structuredinvest.lu/de/en/productpage.html/

LU1899270539

41. https://www.ftadviser.com/investments/2018/12/05/climate-

change-will-have-an-impact-on-all-retail-investors/

42. https://www.bloomberg.com/professional/blog/pensions-

demand-millennials-propel-sustainable-investing-growth

43. https://www.bcg.com/en-gb/publications/2016/financial-

institutions-global-asset-management-2016-doubling-down-on-

data.aspx

44. https://copower.me/en/

45. https://contact.co.nz/aboutus/sustainability/financial-

sustainability

46. https://www.nedbank.co.za/content/nedbank/desktop/gt/en/ personal/save-and-invest/investment-accounts/green-savingsbond.html

47. https://www.climatebonds.net/certification/big60million 48. https://www.climatebonds.net/2014/10/solarcity-issuesus $200 \mathrm{~m}$-retail-bonds-maturity-ranging-1-7-years-coupon-2-4what-pioneering

49. https://www.indiegogo.com/explore/environment

50. https://www.kickstarter.com/discover/tags/go-green

51. https://www.joinmosaic.com/

52. https://sunfunder.com/

53. https://www.triodoscrowdfunding.co.uk/

54. https://www.abundanceinvestment.com/

55. http://www.annual-report-triodos.com/en/2017/servicepages/

downloads/files/annual_report_triodos_ar17.pdf

56. http://www.annual-report-triodos.com/en/2017/impact/

environment.html

57. https://www.triodos-im.com/funds/disclosure

58. https://www.umweltbank.de/ueber-uns/umweltgarantie

59. https://www.yesbank.in/media/press-releases/yes-bank-

launches-green-future-deposit-indias-first-ever-green-deposit-

product

60. http://www.climateaction.org/news/european-banks-launchgreen-mortgage-pilot-scheme

61. https://www.climatebonds.net/resources/reports/green-bondsbridge-sdgs

62. https://www.climatebonds.net/resources/reports/why-makinginfrastructure-climate-adapted-and-resilient-will-help-meet-sd 63. https://www.climatebonds.net/resources/reports/japan-green finance-state-market-2018

64. https://www.climatebonds.net/resources/reports/asean-greenfinance-state-market-2018

65. https://www.climatebonds.net/resources/reports/green-bondmarket-europe

66. https://www.climatebonds net/resources/reports/france-

green-bond-market-overview-opportunities

67. https://www.climatebonds.net/resources/reports/nordic-and-

baltic-public-sector-green-bonds

68. https://www.climatebonds.net/resources/reports/green-bondmarket-nordics

69. https://www.politicalanalysis.co.za/kenya-readies-itself-for-

first-sovereign-green-bond-issue/

70. https://vietnamnews.vn/economy/482413/finance-ministry-

eyes-878b-bond-issuance.html\#6dIOEfpTii5ujq8U.97
71. https://www.climatebonds.net/resources/reports/sovereigngreen-bonds

72. Green Bond Guidelines, Financial Regulatory Authority, Jul 2018: http://www.fra.gov.eg/content/efsa_ar/pool_extra_efsa/ UG43029UG43030.pdf

73. http://www.sec.gov.ph/wp-content/

uploads/2015/10/2018PressRelease

AdoptsTheAseanGreenBondsStandards.pdf

74. https://ec.europa.eu/info/publications/sustainable-finance-

taxonomy_en

75. https://www.mainstreamingclimate.org/ngfs

76. https://www.un.org/sustainabledevelopment/sustainable-

development-goals/

77. https://www.climatebonds.net/files/files/2018-05\%20SP\%20 BBVA.pdf

78. https://shareholdersandinvestors.bbva.com/wp-content/

uploads/2018/04/BBVA-SDGs-Bond-Framework_23042018_Eng. pdf

79. https://www.sustainalytics.com/wp-content/

uploads/2018/10/Korail-Sustainability-Bond-SPO-

FINAL-08292018.pdf

80. https://www.laregion.fr/IMG/pdf/20180808_vigeo_eiris_

opinion_occitanie_region_vf_en.pdf

81. https://www.ingwb.com/insights/news/2018/wilmar-and-ingcollaborate-on-sustainable-loan

82. https://www.sustainalytics.com/wp-content/

uploads/2017/06/Social-Bond-Second-Party-Opinion_NWB.pdf

83. https://www.ico.es/documents/19/69769/

SECOND+OPINION+ICO+Social+Bond+Framework.pdf/44cfbcad-

7f67-4528-ac65-e9eefce8d070

84. https://www.ifc.org/wps/wcm/

connect/5299a595-721b-41ef-90fa-2cff3d50982c/

FINAL+Forests+Bond+Investor+Presentation+10-5 pdf.

pdf?MOD=AJPERES

85. https://www.blueforestconservation.com/\#frb

86. https://www.climatebonds.net/adaptation-and-resilience

87. http://www.snam.it/export/sites/snam-rp/it/investor-

relations/debito_credit_rating/file/Snam_Climate_Action_Bond

Framework.pdf

88. https://ifcextapps.ifc.org/IFCExt/Pressroom/IFCPressRoom.

nsf/0/428E4968C4F86CF3852583B3005B902F

89. https://www.ipcc.ch/sr15/

90. https://www.adb.org/news/asia-infrastructure-needs-exceed-

17-trillion-year-double-previous-estimates

91. https://unfccc.int/sites/default/files/resource/2018\%20

BA\%20Technical\%20Report\%20Final.pd

92. https://www.ifc.org/wps/wcm/connect/topics_ext_content/

ifc_external_corporate_site/climate+business/resources/cioc-ifc-

analysis

93. http://www mission2020 global/

94. http://www.oecd.org/environment/cc/climate-futures/

95. https://www.icmagroup.org/green-social-and-sustainability-

bonds/resource-centre/

96. https://www.reuters.com/article/greenbonds-issuance/

global-green-bond-issuance-forecast-at-140-180-bln-this-year-

idUSL8N1Z943T; https://www.moodys.com/newsandevents/

topics/Green-Bonds-007034

97. http://www.climateaction100.org/

98. https://www.ft.com/content/9421ea96-01e1-11e9-9d01-

cd4d49afbbe3

99. https://www.ft.com/content/8d80c8e4-02f7-11e9-99df-

$6183 \mathrm{~d} 3002 \mathrm{ee} 1$

100. https://www.climatebonds.net/resources/reports/creatinggreen-bond-markets-insights-innovations-and-tools-emergingmarkets

Data sources: Company websites, Bloomberg, Refinitiv EIKON, WIND

Authors: Monica Filkova, CFA, Camille Frandon-Martinez and Amanda Giorgi

Design: Godfrey Design

(C) 2019 Climate Bonds Initiative

Disclaimer: The information contained in this communication does not constitute investment advice in any form and the Climate Bonds Initiative is not an investment adviser. Any reference to a financial organisation or debt instrument or investment product is for information purposes only. Links to external websites are for information purposes only. The Climate Bonds Initiative accepts no responsibility for content on external websites. The Climate Bonds Initiative is not endorsing, recommending or advising on the financial merits or otherwise of any debt instrument or investment product and no information within this communication should be taken as such, nor should any information in this communication be relied upon in making any investment decision. Certification under the Climate Bond Standard only reflects the climate attributes of the use of proceeds of a designated debt instrument. It does not reflect the credit worthiness of the designated debt instrument, nor its compliance with national or international laws. A decision to invest in anything is solely yours. The Climate Bonds Initiative accepts no liability of any kind, for any investment an individual or organisation makes, nor for any investment made by third parties on behalf of an individual or organisation, based in whole or in part on any information contained within this, or any other Climate Bonds Initiative public communication. 


\section{How to issue a green bond / loan / sukuk}

\section{Who can issue green bonds?}

Any entity which has suitable green assets can issue green bonds, green sukuk or obtain a green loan. Suitable green assets include renewable energy, low carbon transport, low carbon buildings, sustainable water and waste management, sustainable land use as well as climate change adaptation measures such as flood defences.
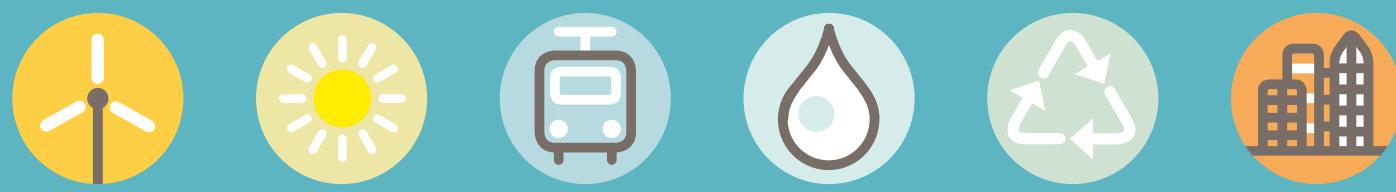

\section{1 Develop a green bond framework}

- Define eligibility criteria for projects/assets

- Create selection process

- Set up tracking \& reporting

\section{Best practice: Arrange an external review}

Assurance report: an external party confirmation of compliance with the GBP/GLP

Second Party Opinion: an external assessment of the issuer's green bond framework, confirming GBP compliance and analysing the eligible asset categories

Green rating: an evaluation of the green bond and framework against a third-party rating methodology, which considers the environmental aspects of the investments. These include products developed by international and local rating agencies such as R\&I (Japan) and RAM (Malaysia)

Verification report for Certified Climate Bond: third party verification, pre- and post-issuance, which confirms that the use of proceeds adheres to the Climate Bonds Standard and Sector Criteria, and the Paris agreement objective of keeping global warming to $2^{\circ} \mathrm{C}$ and achieving full decarbonisation by 2050
Available guidelines \& standards:

International: Green Bond Principles (GBP), Green Loan Principles (GLP), Climate Bonds Taxonomy and Climate Bonds Standard

Regional: ASEAN Green Bond Standards

Country-specific: Ministry of Environment Japan (MoEJ) green bond guidelines and taxonomy

\section{3}

\section{Check for local subsidies \& support} mechanisms:

Singapore: MAS grant scheme can absorb the full cost of external reviews

Malaysia offers tax deduction of issuance costs

for issuers and tax exemptions for investors until 2020

Japan: Subsidies of up to JPY50m available to cover external reviews, green bond advisory and structuring fees

4 Issue the bond, sukuk, loan!

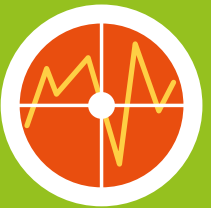

\section{Post-issuance reporting}

Report annually to confirm that the funds are allocated to green projects / assets

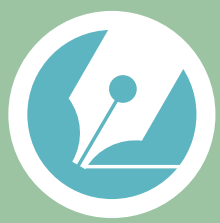

Best practice: Disclose environmental impacts of financed projects in absolute terms and relative to an appropriate benchmark 